\title{
STRUCTURAL, STRATIGRAPHIC AND METALLOGENETIC ASPECTS OF THE PARAGUAY FOLD AND THRUST BELT: IMPLICATIONS FOR GOLD MINERALIZATION AND COLLAGE OF THE GONDWANA
}

\author{
ASPECTOS ESTRUTURAIS, ESTRATIGRÁFICOS E METALOGENÉTICOS DO CINTURÃO DE \\ DOBRAMENTOS E DE CAVALGAMENTOS DE PARAGUAI: IMPLICAÇÕES PARA A \\ MINERALIZAÇÃO DE OURO E COLAGEM DO GONDWANA
}

\section{Elzio da Silva BARBOZA ${ }^{1,2}$, Mauro César GERALDES ${ }^{2}$, Francisco Egídio Cavalcante PINHO $^{1}$, Carlos José FERNANDES ${ }^{1}$, Carlos Humberto da SILVA ${ }^{1}$ \\ ${ }^{1}$ Universidade Federal do Mato Grosso. Grupo de Pesquisas Recursos Minerais de Mato Grosso. Av. Fernando Corrêa da Costa, 2367 - Bairro Boa Esperança. Cuiabá - MT. E-mails: aguapei@yahoo.com; carlosjfer@yahoo.com.br, chsilva2@yahoo.com.br ${ }^{2}$ Universidade do Estado do Rio de Janeiro. Faculdade de Geologia. Rua Amapá, 11 - Vila do Abraão, Abraão - RJ. E-mails.elziosb@yahoo.com.br, geraldesl@uerj.br}

\author{
Introduction \\ Regional Geology \\ Structural Aspects \\ Metalogenetic Aspects \\ Local Studies \\ Guia Syncline \\ Casa de Pedra Gold Deposit \\ Cangas Gold Deposits \\ São Vicente Granite \\ Conclusions \\ Acknowledgments \\ References
}

\begin{abstract}
Paraguay Belt occupies the western portion of the Tocantins Province, surrounding the Southeast of the Amazonian Craton and the eastern border of the Rio Apa Block, suggesting continuity with Tucavaca Belt in Bolivia. The rocks of the Paraguay belt were initially deposited in a glaciomarine environment in sites proximal to the cratonic area and deeper marine under the influence of turbidite flows in distal sites (Cuiabá Group, Bauxi and Puga Formation). The cap carbonates, thick limestone and dolostone succession of the Araras Group and siltstones and diamictites of the Serra Azul Formation related to Glaskiers glaciation overlay these diamictites (related to Marinoan glaciation). On the top there are terrigenous sediments of the Alto Paraguay Group, represented by sandstones of Raizama and claystones of Diamantino formations, respectively. The belt can be divided into three distinct structural zones: The Internal Domain is comprised of turbidite and glaciogenic sequences. Glaciogenic rocks on the base and carbonaceous and terrigenous sediments on the top occur in the External Domain. Horizontal platformal cover on the Amazonian Craton rocks are characterized by open folds. Structural studies allowed characterization of continuous deformational phases: the main deformational phase generated regional inverse folds with a NE-SW trend and fan geometry. Several regionally widespread lode-type gold deposits related to four types of the quartz veins were identified: type 1 is in concordance to bedding, type 2 is parallel to Sn, type 3 is parallel to $\mathrm{Sn+2}$, and vertical Type 4 (Au-rich) is orthogonal to Sn. Late deformation developed in the Cuiabá region, recorded the closure of the ocean and the invertion where the hydrothermal fluids are the responsible for the orebodies formation.

Keywords: Paraguay Belt, Structural, Stratigraphy, Metalogenesis.
\end{abstract}

RESUMO - O Cinturão do Paraguai ocupa a porção oeste da Província do Tocantins, ao redor do sudeste do Cráton Amazônico e a leste do Bloco Rio Apa e aparenta ter continuidade com o Cinturão Tucavaca na Bolivia. As rochas do cinturão do Paraguai foram inicialmente depositadas em um ambiente glaciomarino em locais próximos à área cratônica (Formação Puga) e marinhos mais profundos sob a influência dos fluxos de turbidito em locais distais (Grupo Cuiabá e Formação Bauxi). Os carbonatos de topo e dolomitos do Grupo Araras e siltitos e diamictitos da Formação Serra Azul provavelmente estão relacionados à glaciação Glaskiers que cobrem os diamictitos relacionados à glaciação Marinoana. No topo, existem sedimentos terrestres do Grupo Alto Paraguai, representados por arenitos da Formação Raizama e arenitos da Formação Diamantino. O cinturão pode ser dividido em três zonas estruturais distintas: O Domínio Interno é constituído por turbiditos e sequências glaciogênicas. Rochas glaciogênicas na base e sedimentos carbonáticos no topo ocorrem no domínio externo. Outros sedimentos com dobras abertas ocorrem na área do Cráton da Amazônia e é caracterizado como uma cobertura platformal. Os estudos estruturais sugerem fases deformacionais contínuas, sendo a principal fase deformacional responsável pela formação de dobras inversas vergência NE-SW e geometria tipo fan. Foram identificados vários depósitos de ouro do tipo filão relacionados a quatro tipos de veios de quartzo: o tipo 1 é paralelo ao acamamento; o tipo 2 é paralelo ao Sn; o tipo 3 é paralelo ao Sn + 2; e o tipo 4 é ortogonal a Sn, sendo o mais enriquecido em Au. As deformações desenvolvidas na região de Cuiabá registraram a deposição em ambiente marinho e inversão tectônica, onde os fluidos metamórficos são os responsáveis pelas mineralizações.

Keywords: Cinturão Paraguay, Estrutural, Estratigrafia, Metalogêne.

\section{INTRODUCTION}

The Paraguay belt developed on the southern the east border of the Rio Apa Block (Almeida, border of the Amazonian Craton Province and 1984 and Alvarenga et al., 2004). The origin of 
the sedimentation of the marine facies may be correlated to a continental to marine (platformal) basin that originated at about $800 \mathrm{Ma}$ followed by inversion related to collision of the Amazonian Craton and the Paranapanena Block.

The Paraguay belt may be included among the diachronous orogenies, correlated to the Gondwana assembly, where the closure of many oceans was responsible for the collage of older continental fragments.
The Paraguay belt is bordered in the North by the Amazonian Craton, and in the South it is covered by Fanerozoic sediments of the Paraná, Parecis and Pantanal basins.

The western border is limited by the PaleoMesoproteozoic Rio Apa Block. This belt comprises a N-S trend (southern and central sector) and a W-E trend in the region of Nova Xavantina (eastern sector), (Figure 1), approximately $1500 \mathrm{~km}$ long and $300 \mathrm{~km}$ wide.

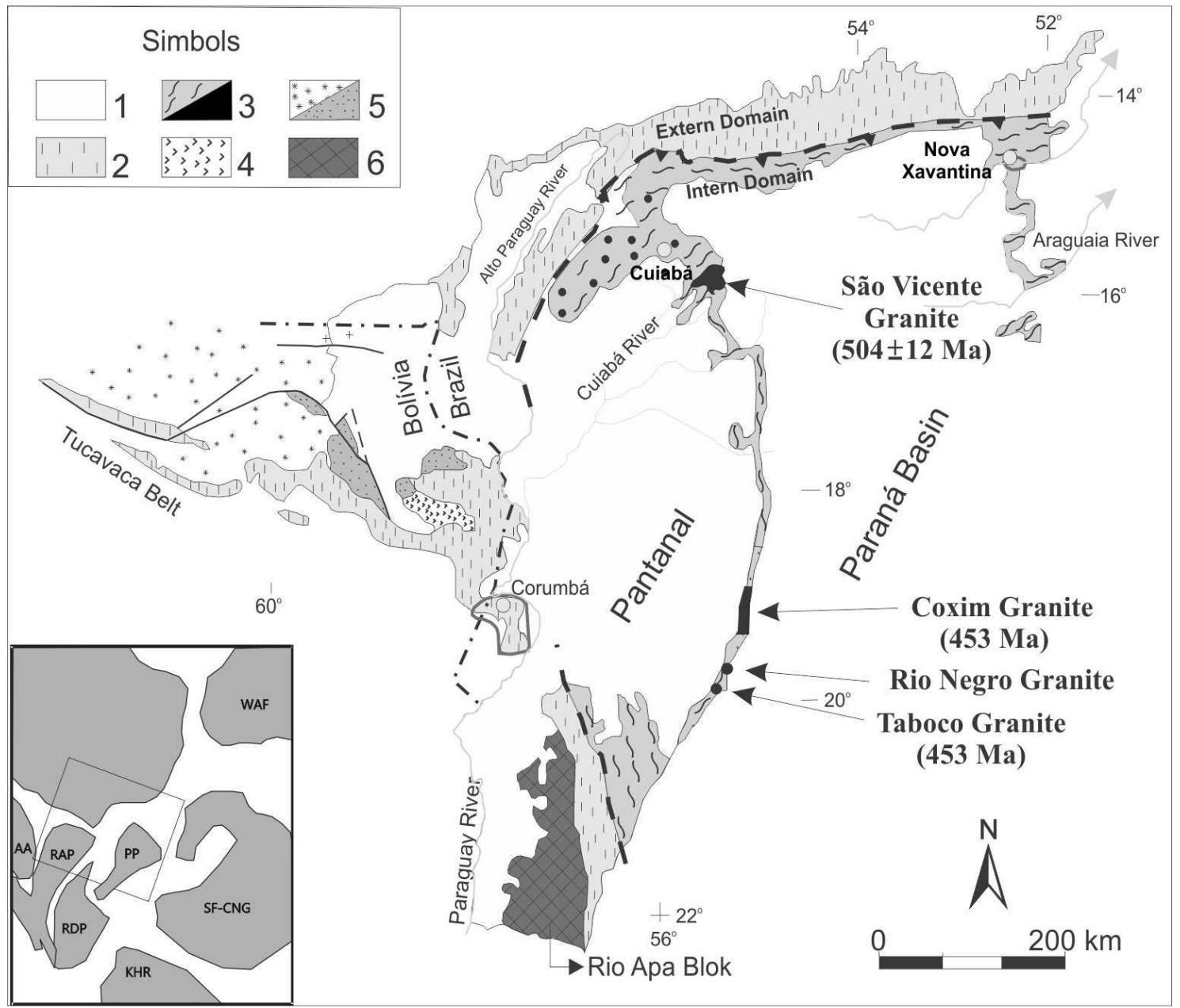

Figure 1 - Regional context of the Paraguay Belt. 1-Fanerozoic covering; 2-Platform cover Neoproterozoic/Cambrian of the Paraguay Belt; 3-Metassediments and granites of the Paraguay Belt; 4-Mafic-Ultramafic Rincon del Tigre; 5Metassediments and granitoids of the Sunsás and Rondônia-San Ignácio Mobile Belts; 6 Gnaisses and granitoids of the Rio Apa Complex. Insert according to Brito Neves et al. (1999). (WAF-West Africa; KHR-Kalarari; SF-CNG São Francisco-Congo; RDP-Rio de La Plata; PP-Paranapanema; AA-Arequipa.

The first publication on the Paraguay Belt was by Evans (1894 in Luz et. al., 1980), in which he described folded sedimentary rocks in the northern sector of the belt.

Recently, the region was investigated by several authors in different studies geochemical and stratigraphic aspects (Alvarenga \& Saes, 1992; Boggiani et al., 1993, Alvarenga et al., 2004) and structural aspects (Luz et al., 1980; Alvarenga, 1984; Pires et al., 1986; Broggi et al., 1994; Costa et al., 1998; Silva, 1999; Migliorini, 1999;
Hortensi, 1999; Silva et al., 2002, Barboza \& Santos, 2003, Barboza et al 2003) and an important contribution to tectonic evolution was reported by Alvarenga \& Trompette (1993), Alvarenga et al., 2004, 2006).

The available data of the Paraguay Belt suggest Neoproterozoic to Cambrian ages for the collision process. According to Cordani et al. (1985), the $\mathrm{Rb} / \mathrm{Sr}$ age of $660 \pm 60 \mathrm{Ma}$ ( $\mathrm{Ri}=0.7082)$ in sediments may be interpreted as diagenetic age constraints. Barros et al. (1982) presented a $\mathrm{Rb} / \mathrm{Sr}$ age of $484 \pm 19 \mathrm{Ma}(\mathrm{Ri}$ 
$=0,743$ ) for phyllites, interpreted as the metamorphic record of the final stage of the orogenic evolution. The crystallization ages of the late orogenic igneous rocks of São Vicente Granite are indicated by $\mathrm{Rb} / \mathrm{Sr}$ isochron of $504 \pm 12 \mathrm{Ma}$ (Almeida \& Mantovani, 1975). The Ponta do Morro Complex rocks (Souza, 1997) show a $\mathrm{Rb} / \mathrm{Sr}$ age of $480 \mathrm{Ma}$ (Del'Arco et al., 1981) and Coxim and Taboco granites yielded a K/Ar cooling age of $453 \mathrm{Ma}$ (Luz et al., 1980). The Ar/Ar age intervals between $541 \mathrm{Ma}$ and $531 \mathrm{Ma}$ indicated the cooling age of the metamorphic process for the Cuiabá Group rocks in the Nova Xavantina region (Geraldes et al., 2003). The variation of the ages allows ordering of the events; moreover, additional geochronological studies are necessary to establish the complete evolution of the tectonic events in the Paraguay Belt.

The sedimentary rocks were deposited and subsequently metamorphosed in greenchist facies conditions as a result of the Amazonian Craton and Paranapanema Block collision.

In a regional cross section, it is possible to distinguish three structural zones: the Internal,
External and Platformal Structural Domains (Alvarenga \& Trompette, 1993). The first domain comprises the turbidites glaciogenic sequences, which are strongly folded and metamorphosed in greenchist facies and intruded by granitic bodies. Glaciogenic rocks on the base and carbonaceous and terrigenous sediments on the top occur in the second domain (External Domain), which are lightly folded but not metamorphosed. These sequences have a flat horizontal extension covering the Amazonian Craton in the Platformal Domain. The limit between the internal and external zone is marked by inverse faults that are laterally limited by transference faults.

This contribution deals with structural, stratigraphic and metallogenetic aspects of the Paraguay Belt. For this purpose, four sites located in the internal zone were studied: Cangas and Casa de Pedra gold deposits, São Vicente Granite and Guia carbonate quarries. In the external zone, Nobres region was studied based on integrated lithostratigraphic and structural analysis.

\section{REGIONAL GEOLOGY}

The Paraguay Belt presents a depositional history recorded in different portions of the belt. In the southern portion, Boggiani et al. (1993) and Gaucher et al. (2003) reported stratigraphic sequences of the Serra da Bodoquena. In the Cuiabá (central) region, Luz et al. (1980), Almeida (1984), Alvarenga et al. (2004, 2006), Migliorini (1999) and Alvarenga \& Saes (1992) described the main stratigraphic units. Martinelli (1999) and Pinho (1990) reported geologic aspects of the Paraguay belt in the Nova Xavantina region (eastern sector). Luz et al. (1980), Nogueira et al. (2003) and Figueiredo et al. (2004) presented important stratigraphic aspects of the sedimentation in the Platformal domain.

\section{Stratigraphic aspects}

The sedimentary rocks of the Paraguay Belt were deposited within a continental margin basin, probably ca. 800-550 Ma. In the Nova Xavantina region, the probable basal sequence of the Paraguay Belt occurs, comprised of basic and ultrabasic volcanic rocks, interbedded with claystones and sandstones, named the Volcanosedimentar Nova Xavantina Sequence (Pinho, 1990; Martinelli, 1999).

There are many suggestions concerning the stratigraphic components of the Paraguay Belt (Almeida, 1964 and 1984; Hennies, 1966) in the literature. These stratigraphic studies defined the Cuiabá Group on the base, overlain by Bauxi and Puga formations and the Alto Paraguay Group (Araras, Raizama and Diamantino Formation) on the top. Later, Alvarenga (1984) named only the Guia unit as a facies of the Araras Formation. Nogueira (2003) suggested four formations for the Araras unit. The Alto Paraguay Group including Raizama and Diamantino formations remain unchanged as described by the early researchers. In addition (Alvarenga et al., 2006, Figueiredo, 2006), the Araras Formation was divided into the Guia and Nobres formations to separate the calcareous from the dolostone rocks, in this way corroborating Hennies (1966) descriptions.

During the first systematic geologic mapping in the Cuiabá region $(1: 100.000$ scale), the rocks of the internal zone (Cuiabá Group) were divided into nine subunits, according to Luz et al. (1980). These authors indicated the following sequences from the base to the top: 1) sericitic phyllite with alternances of graphitic phyllite and sand-stones; 2) feldspatic sandstones and meta-graywakes, 
graphitic phyllites with alternances of calciferous marble; 3) phyllite, phyllite with conglomerate, conglomerates, graywakes and sandstones, alternances of the quartzites, lenses of calcitic marbles with hematite on the top; 4) diamictites with polimitic clasts and siltic-sandstone matrix;
5) phyllite and sericitic phyllite with alternations of feldspatic-rich sandstones and conglomerates; 6) phyllite conglomeratics; 7) diamictites with minor sandstones; 8) marble and calcareous with lenses of dolomites and pelites on the top; and 9) undivided (Figure 2).

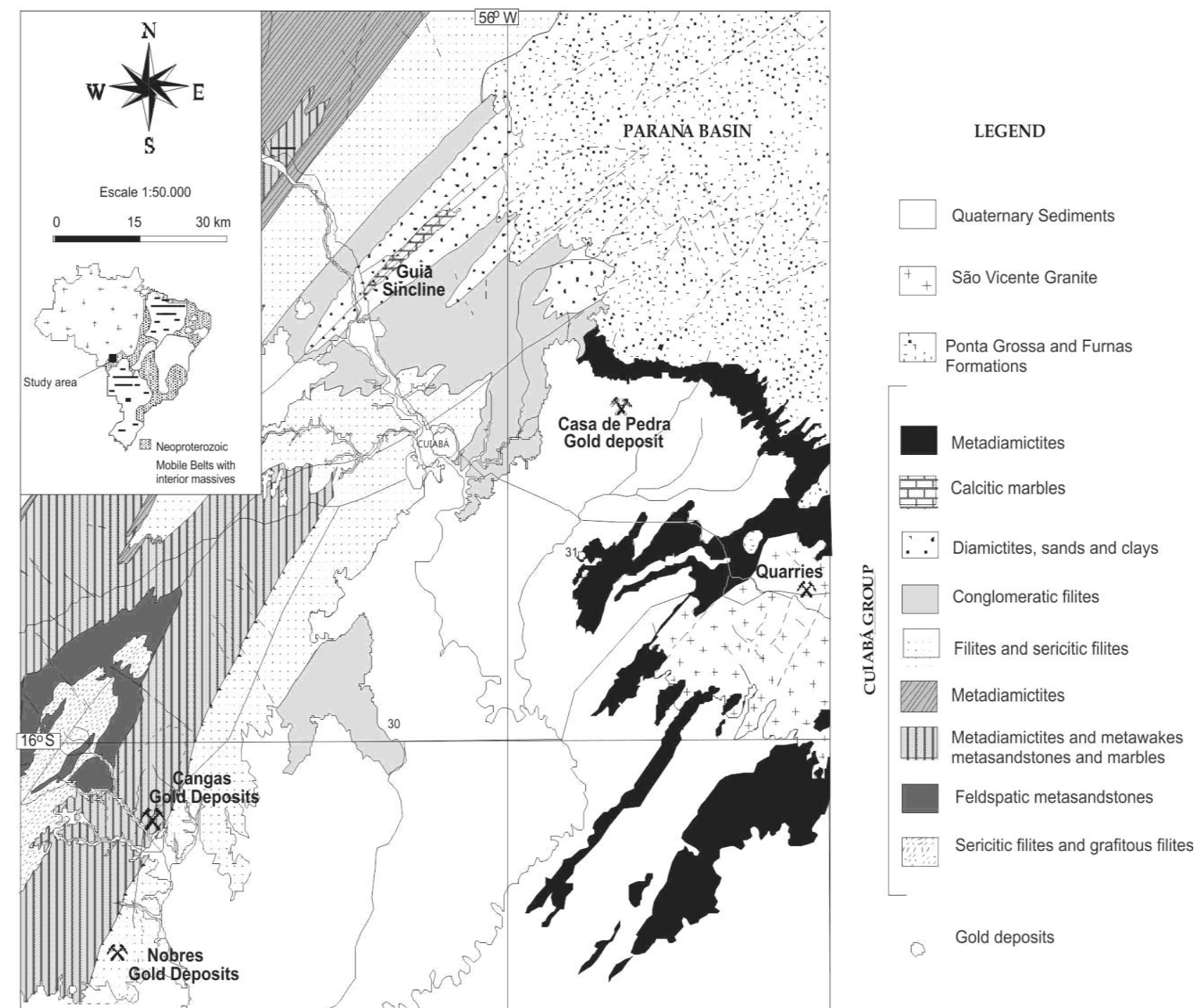

Figure 2 - Geology of the internal zone of the Paraguay Belt in the Cuiabá and Poconé regions (modified from Luz et al., 1980).

Alvarenga (1984) proposed a stratigraphic subdivision of the Paraguay belt. The Lower Unit is similar to subunits 1 and 2, as described above (according to Luz et al., 1980); the Intermediate Units present distal facies, similar to an undivided subunit, including subunits 3 and 5 (according to Luz et al., 1980) and proximal facies (Bauxi and Puga formations) correlating to subunits 4 and 7. The Carbonate unit occurs in the Cratonic area as Araras Group and is correlated to unit 8, represented by Guia carbonates in the internal zone. The Superior Units, according to Alvarenga (1984), only occur in the Cratonic areas; they include the Raizama Formation composed of quartz feldspatic sandstones and clay wakes and the Diamantino Formation composed of siltistones, shales and wakes.

Alvarenga \& Trompette (1992) and Alvarenga et al. (2006) described the rocks of the Cuiabá Group as constituted of organic-rich phyllite and metadolostones, overlain with glaciogenetic and turbiditics metassediments such as diamictites, conglomerates, sandstones and shales. This sequence grades towards the Cratonic area to Bauxi and Puga formations (Figure 3). This lateral gradation of the Paraguay Belt was first suggested by Almeida (1964) and other authors (Alvarenga, 1984; Alvarenga \& Trompette, 1993). The Bauxi Formation is composed by diamictites, siltstones, quartzites and conglomerates, which were deposited in a glacial environment. The Puga Formation is mainly 


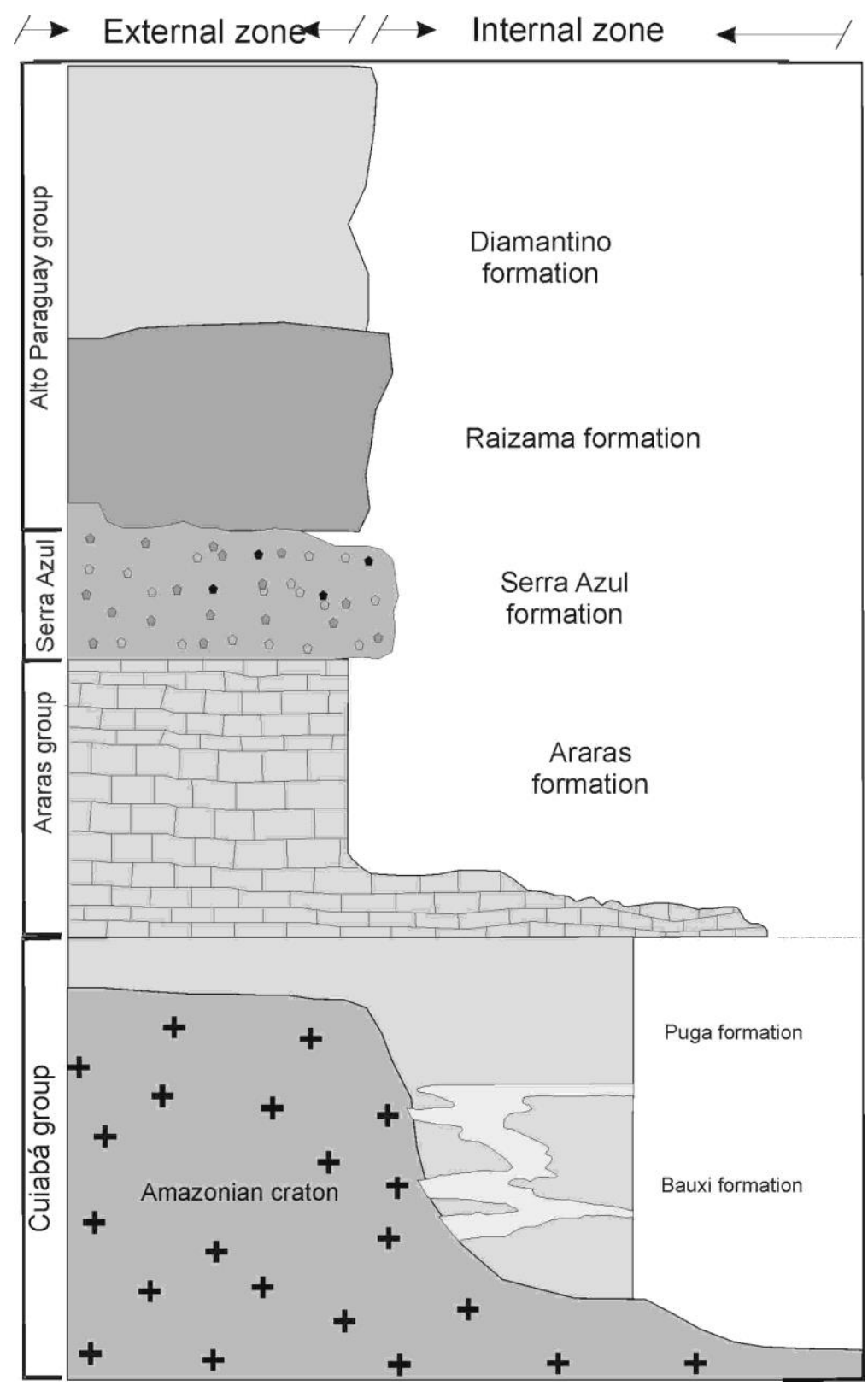

Figure 3 - Stratigraphic column of the Paraguay Belt in the Mato Grosso state (modified by Alvarenga, 1984; and Figueiredo, 2006).

constituted of diamictites; it occurs principally in the Cratonic area and is correlated to Marinoan glaciation (according to Nogueira et al., 2007; Alvarenga et al., 2004; Trindade, 2003). The origin of these rocks is interpreted as a product of gravitational flux and overlay by cap-carbonates of the Araras Group (Alvarenga, 1984).

The Araras Group rocks were studied for $\mathrm{Sr}$, C and O isotopes by Nogueira et al. (2003), utilizing facies studies to interpret the paleoenvironmental evolution, with characterization of four carbonates units. These tools permitted the authors to characterize four carbonate units: Mirassol d'Oeste (cap carbonate), Guia, Morro do Quilombo and Nobres formations. These formations may be correlated to the Cerradinho, Bocaina, Tamengo and Guaicurus formations
(Corumbá Group) in the South of the Paraguay Belt, as described by Gaucher et al. (2003).

Based on Ediacarian fossiliferous contents, Boggiani et al. (1993) suggested that the Corumbá Group is not correlated to the Araras Group. The fossils in the Corumbá Group suggest Vendian ages instead of the VarangianMarinoan ages yielded by the $\mathrm{C}$ isotope signatures (Nogueira et al., 2003) or 590-550 Ma (according to Pinho et al., 2003).

Recently, a new formation has been proposed in the top of Araras Group, named Serra Azul Formation (Figueiredo et al., 2004; Figueiredo, 2006 and Alvarenga et al., 2006). This formation was described in the Marzagão District (External Domain) as massive diamictite at the base followed by a sequence of laminated mudstones, 
siltstones and fine sandstones on the top. The origin of this unit was probably related to the Gaskiers Glaciations (ca. 580 Ma age) in agreement with the above authors.

\section{Tectonic aspects}

The structural domains of the Paraguay Belt have been described by Luz et al. (1980) and Alvarenga (1990), Piacenti et al. (2007) and Campanha et al. (2011); complementary studies have been proposed in unpublished reports written by the authors in recent years and presented below.

Sedimentary rocks metamorphosed at the greenchist facie constitute the internal zone and structural evolution is described by continuous deformational phases as proposed by Ruiz et al. (1999). The structural patterns and geometry of the belt is mainly characterized by regional trends, such as inverse regional folds and locally recumbent folds, and indicate mass transport from S-SE to N-NW in the Internal Domain, as observed in the Cuiabá and Poconé regions (Ruiz et al., 1999). Silva (1999) described a fan geometry for the main deformation phases, suggesting transport to the Cratonic area in the Platformal Domain. There are late transversal fractures (NW trend) which are filled by $\mathrm{Au}-$ bearing quartz veins, for-med during orogeny collapse (Alvarenga, 1990).
The deformed rocks of the External Domain are interpreted as a record of the compressive tectonics that occurred at the Internal Domain during the evolution of the Paraguay Belt. Within the External Domain, the metamorphism is incipient or totally absent, but the package of rocks is folded, with symmetrical or lightly asymmetrical patterns with axial planes trending N20-30E. The transference faults (strike NW) are also visible in External Domain, and they are responsible for transporting the Internal and External Domain rocks into contact. Otherwise, the structural patterns of the rocks in the Platformal Domain are characterized by gradual changes. Towards the Amazonian Craton, deformation is less penetrative, and metamorphism is absent, with flat sediments of the Araras and Alto Paraguay Groups.

Lithological characteristics and structural analysis carried out in the Nobres region in the External Domain, and in Cuiabá, Poconé and Guia in the Internal Domain of the Paraguay Belt, were done for didactic purposes with students of the Cuiaba Geology Course during several field trips. The field data in addition to large bibliographical revision supplied subsidies to suggest that four continuous deformation phases had affected the rocks of the Cuiabá Group in the Internal Domain of the Paraguay Belt (Figure 4).

Figure 4 -Schematic model showing the foliation planes in relation to the folds in the internal zone of the Paraguay Belt.

The first deformation $\left(\underline{D}_{n}\right)$ was responsible for the generation of asymmetrical and inverse regional scale folds, showing SE vergence in the Cuiabá and Poconé regions. Crossing to the external zone, their style changed to vertical and NW vergence by showing a fan geometry (Silva, 1990, 1999). The stretching lineation is marked by the alignment of the flattened clasts in the $S_{n}$ surface that shows soft Northeast inclination within the External Domain.

The second phase $\left(D_{n+1}\right)$ produced open, lightly asymmetrical folds and the axial surface $\left(\mathrm{S}_{\mathrm{n}+1}\right)$ dipping $\mathrm{SE}$, resulting a NW vergence with NE plunging. Cleavages are frequent.

The third phase $\left(D_{n+2}\right)$ also occurs as asymmetrical folds on a metric scale with SW and 
NE axes plunging but can also occur as kink bands; in the Cangas gold deposits, these folds are not totally co-axial (locally) with the previous phases.

The fourth phase $\left(D_{n+3}\right)$ is orthogonal to the previous phases of deformation. It has brittle characteristics and occurs as open folds on the kilometric scale, locally as cleavage of fracture with SW and NE dipping orientation. In the auriferous deposits, located at the Internal Domain, the best gold grades are linked to milky quartz veins.

The proposal of three coaxial phases and a fourth orthogonal phase were supported by Trompette (1994). According to these authors, the first phase does not show clear vergence, the second phase has a SE vergence, and the third phase presents vergence in direction to the Amazonian Craton, which is only visible in the non-metamorphic rocks that cover the craton.

\section{Orebodies origin}

Within the Internal Domain, small companies exploit the auriferous deposits in open pits. The ore is comprised of quartz veins and disseminations in the host diamictitic rocks of the Cuiabá Group. According to Alvarenga (1990) and Silva et al. (2002), there are three structural types of quartz veins in some deposits of the region (including the Casa de Pedra), where the first and the second type are in the NE direction and the third is in the NW direction. The first type (1) is parallel to the $S_{0}$ bedding, the second type (2) is parallel to $\mathrm{Sn}$, and the third (3) is orthogonal (NW) to the regional structure. Regionally, type 1 and 2 quartz veins are Alvarenga \& Trompetti (1993) and also by

parallel (Alvarenga, 1990 and Silva et al., 2002). Geraldes et al. (2018) reported Ar-Ar ages for the mineralizing process about $541.6 \pm 0.4 \mathrm{Ma}$ to 531 $\pm 0.6 \mathrm{Ma}$ and define the cooling period of regional metamorphic event related to the collision between the Amazonian craton and Paranapanema block, the final stages of the western Gondwana assembly (Barboza et al., 2005).

A centimetric halo of hydrothermal alteration with red and green color (due to percolation of iron and manganese oxides) may be observed along the quartz veins. In the auriferous deposits studied, carbonate grains spread in the hosted rock as nodules up to $1 \mathrm{~cm}$ of diameter. In the Cangas gold deposits, four types of quartz veins may be described, according to Dowling \& Morrinson (1989), using orientation, geometry and textural aspects as criteria.

Alvarenga (1984) sampled quartz veins to study fluid inclusions from Casa de Pedra gold deposits, the BR-070 cut road and one site adjacent to Jangada city. The results indicate the presence of a variable quantity of $\mathrm{CO}_{2}, \mathrm{CH}_{4}$ and $\mathrm{N}_{2}$, homogenization temperatures between $250-380^{\circ} \mathrm{C}$ and low salinity (minor than $10 \%$ weight eq. $\mathrm{NaCl}$ ), associated with later fluid inclusions. After that, $\mathrm{H}_{2} \mathrm{O}$-rich homogenization occurred at a temperature of approximately $120-180^{\circ} \mathrm{C}$, a salinity of approximately 2-9\% weight eq. $\mathrm{NaCl}$ and pressures between 1 and 2 Kbars. Campos et al. (1987) investigated (using fluid inclusions) the possible link between fluids and auriferous deposits with the granite intrusion; however, no relationship was found.

\section{LOCAL STUDIES}

To gain a better understanding of the structural and tectonic aspects of the Paraguay Belt, five local studies in different sites in the Paraguay Belt were carried out, selected according to wide distribution and in both Internal and External Domain locations. Therefore, we selected the Nobres region in the External Domain; Cangas and Casa de Pedra gold deposits, São Vicente Granite and Guia carbonate quarries were selected in the Internal Domain (Barboza and Geraldes, 2004; Barboza et al., 2018). In all of these sites (Figure 1), litho-structural studies were performed, as described below.

The region of Nobres city is located in the External Domain of the Paraguay Belt, about 150 $\mathrm{Km}$ to the northwest of Cuiabá city (Figure 5), where it is possible to observe all stratigraphical columns of the External Domain. In Serra Azul, the eastern portion of Nobres, Figueiredo (2006) described a wide inverse fold and asymmetrical anticline where the Puga Formation (diamictites), Mirassol d'Oeste Formation (dolonstones), Serra Azul Formation (diamictite and claystones), Raizama Formation (sandstones and conglomerates) and Diamantino Formation (siltistones and claystones) are observed. Around Nobres city, the stratigraphic units are very similar to those of the Marzagão area, but the diamictites of the Serra Azul Formation were not observed. However, in a road cut next to the Serragem River, there occurs a package of siltstones, claystones and laminated mudstones, similar to those described by Figueiredo et al. (2004). 

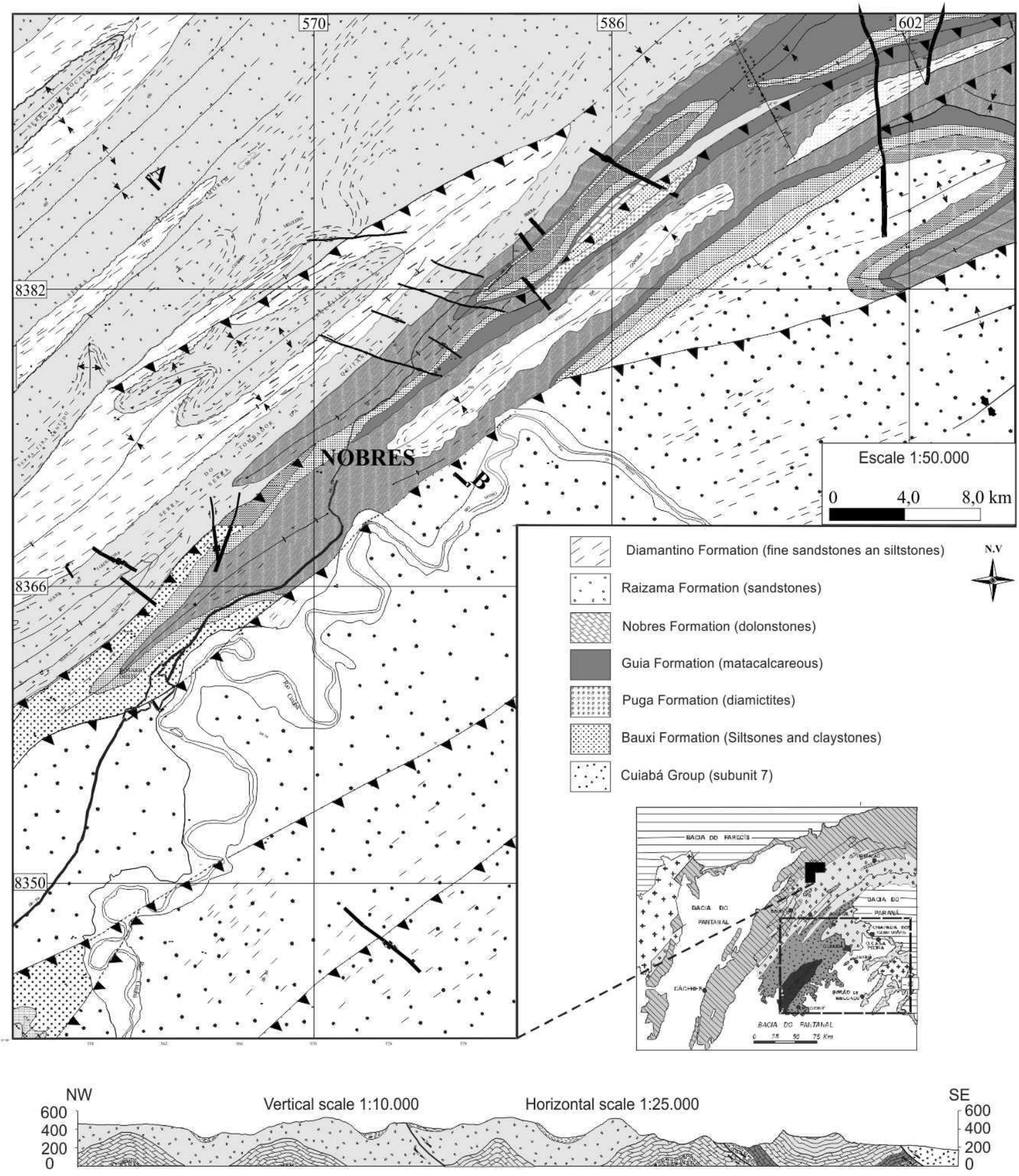

A

B

Figure 5 - Geological map of the Nobres region. Details of inverse faults (thrust) are shown, putting the rocks of Cuiabá Group (External Domain, S-SE) in contact with Puga and Bauxi, Araras and Alto Paraguay Formations (External Domain, N-NW).

The main structures observed are wide folds on a regional scale and symmetrical or soft asymmetrical folds in Nobres. Thrust faults placed different packages into contact (see map in Figure 5). This tectonic limit placed strongly folded rocks, showing vergence to NW, together with soft symmetrical folded rocks. The deformations and metamorphism within the External Domain are absent or incipient; however, local foliation (parallel to $\mathrm{S}_{0}$, Figure $6 \mathrm{~A}$ and $\mathrm{B}$ ) is observed in diamictites of the Puga Formation, claystones of the Serra Azul and limestones of the Araras Group, whereas in dolostones, it appears as fractures and breccias. The fracture systems in the sedimentary rocks present a northwest strike and dip to the Southwest and Northeast (Figure $6 \mathrm{C}$ ). Locally, these fractures are mainly filled with amorphous siliceous, quartz or calcites in the limestone and dolonstones. Other fractures have a northeast strike and dip to the southeast, which coincides with the cleavage that is generally present in the Cuiabá Group. 
A

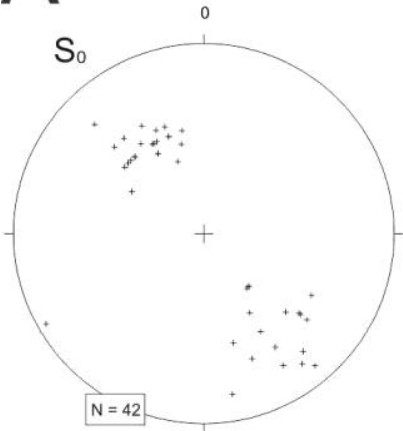

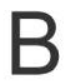

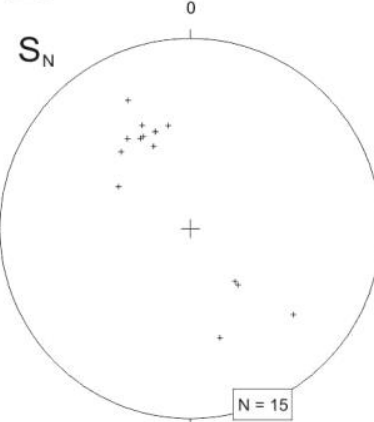

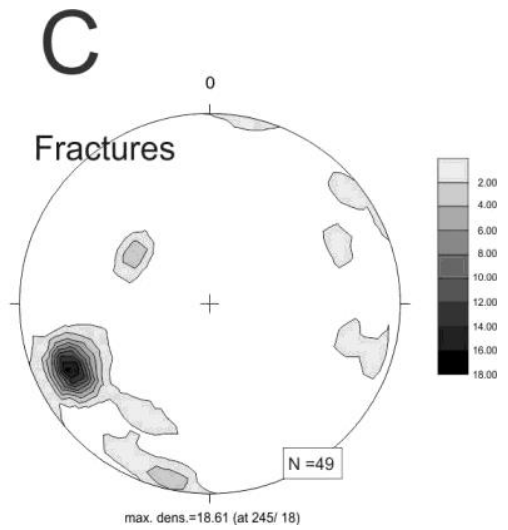

C

Figure 6 - Structural diagrams of Nobres region.

The Guia Syncline is an asymmetrical, inverted synform on kilometric scale, forming the Guia mountain range. The rocks that crop out inside this structure are diamictites, filites, metacalcareous, metasiltstones, metadolostones and metagraywakes (Figure 7). The Sn foliation show parallel orientation to the axial plan of the regional folds. This foliation is marked by orientation of the micaceous mineral, whereas the foliation planes in the metadiamictites are defined by pebble orientation in a clay-silty matrix.

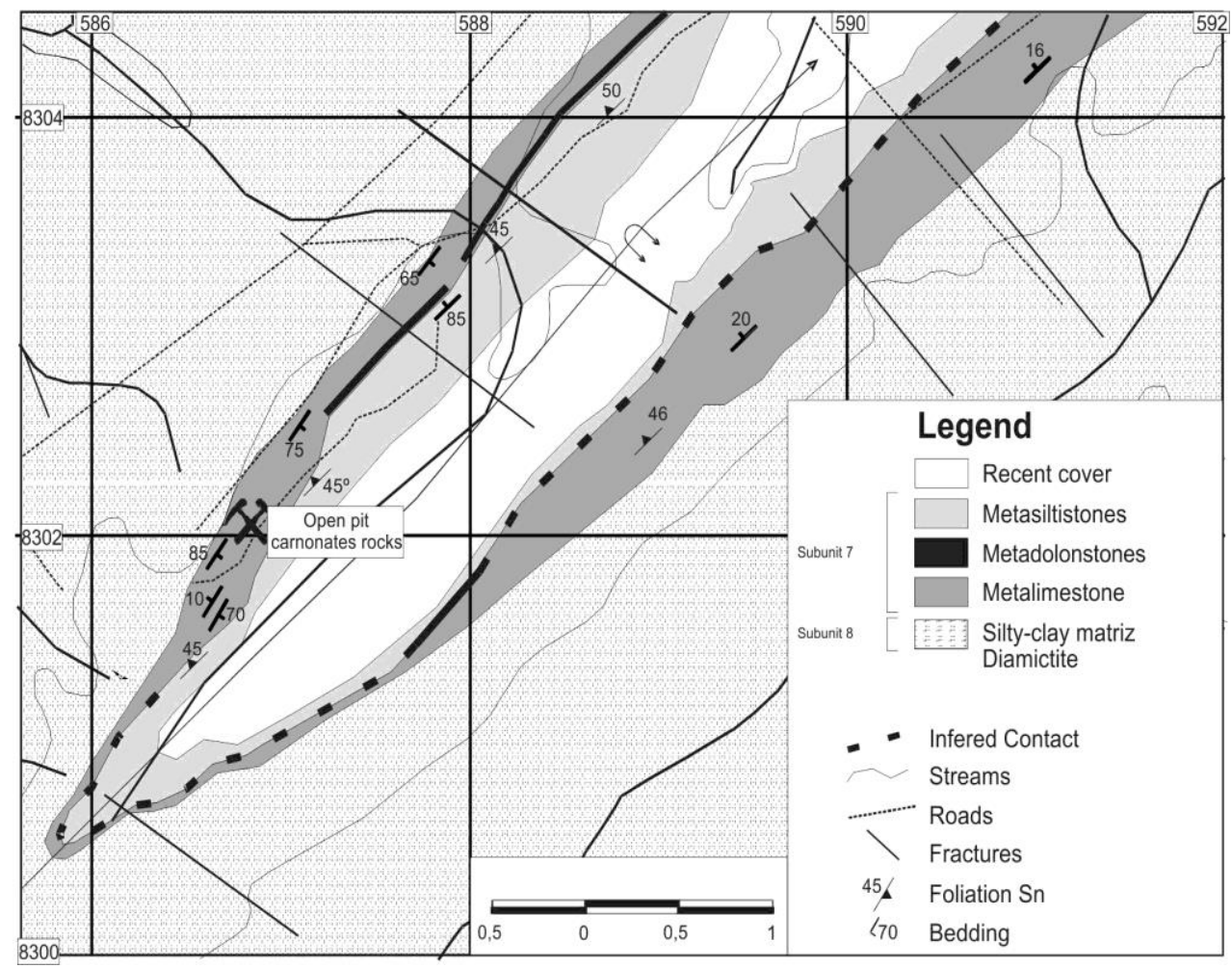

Figure 7 - Geologic map of Guia Syncline core (open pit of carbonate rocks).

This foliation (Sn, Figure 8B) can appear in the form of slate cleavage in the metalimestone and metagrauwakes, even in metadolostones. The orientation of this foliation is $\mathrm{N} 40^{\circ} \mathrm{E}$, with a $60^{\circ}$ dip to the NW, and the axes of the folds show a soft plugging between $10^{\circ}$ and $15^{\circ}$ for NE. The Dn+1 phase generated the foliation $\mathrm{Sn}+1$ (Figure 8C) marked by the axial plan of opened folds, whose amplitude had few meters of extension. Its average attitude is about $\mathrm{N} 39^{\circ} / 48^{\circ} \mathrm{SE}$. This foliation is only visible in the metagrayvakes and metadiamictites. The third $\mathrm{Dn}+2$ phase was not visualized in the Guia syncline.

The fourth deformational phase is represented by a $10-20 \mathrm{~cm}$ spaced cleavage in limestones and metagrauwakes but also appears discretely as an axial surface ( $\mathrm{Sn}+2$, Figure 8 D) of metric opened folds, visualized on metagrauwakes of the internal portion of the synform or as crenulations and kink bands in the diamictites in the hinge of the structure. 

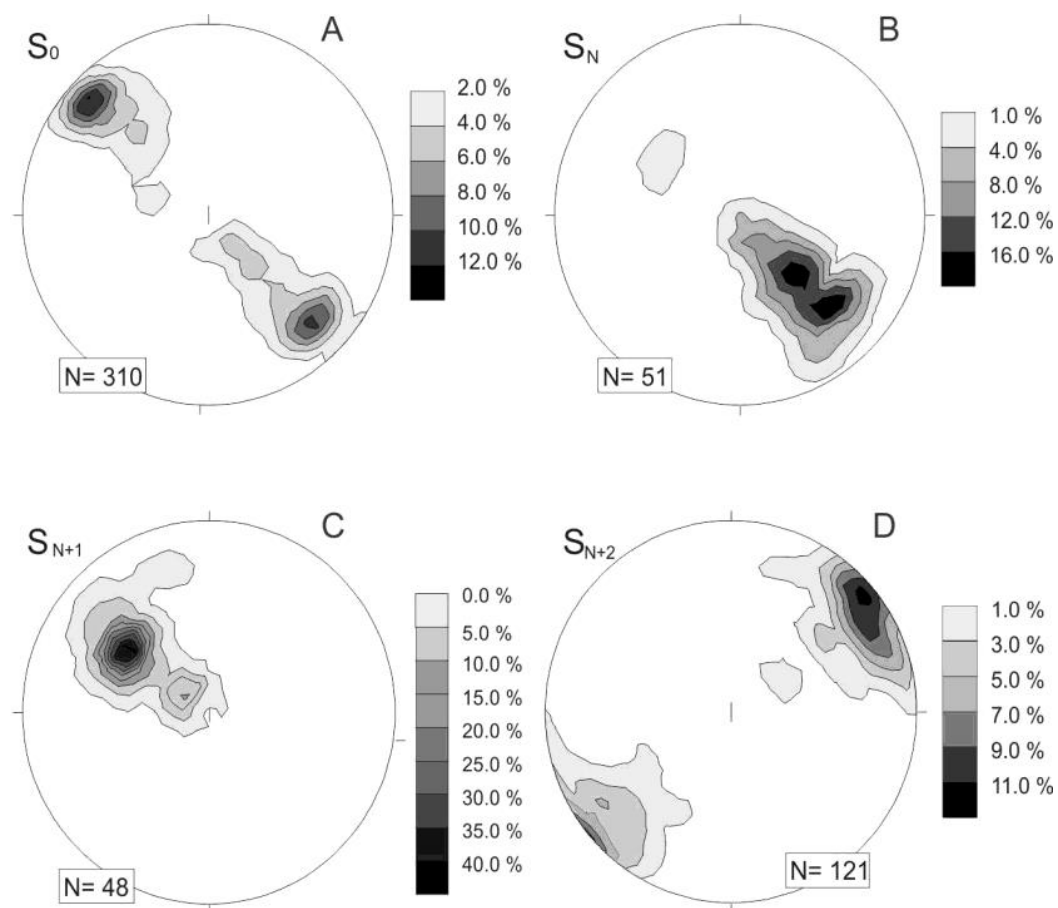

Figure 8 - Structural diagrams of Guia Syncline. $S_{0}=$ bedding; $S_{n}=$ foliation; $S n+1=$ foliation generated during the Dn+1 deformational phase; $\mathrm{Sn}+2=$ foliation generated during the $\mathrm{Dn}+2$ deformational phase.

Regionally, the fourth phase of deformation has its axial plan marked by the presence of Au-rich quartz veins. In the Guia syncline, these fractures are filled by calcite and quartz and locally contain hydrothermal pyrite.

Casa de Pedra auriferous deposit is located 35 $\mathrm{km}$ in the Northeast of Cuiabá (Figure 2). The gold occurs in association with quartz veins and/or disseminate in the host rocks of the Cuiabá Group according to Alvarenga (1990) and an undivided unit, according to Luz et al. (1980). The mineralized host rocks are composed of sericitic phyllites, metasiltistones and metadiamictites (Figure 9). The mineral association is quartz, chlorite, biotite, albite, carbonates, epidote, rutile and ore mineral as pyrite, chalcopyrite and hematite.

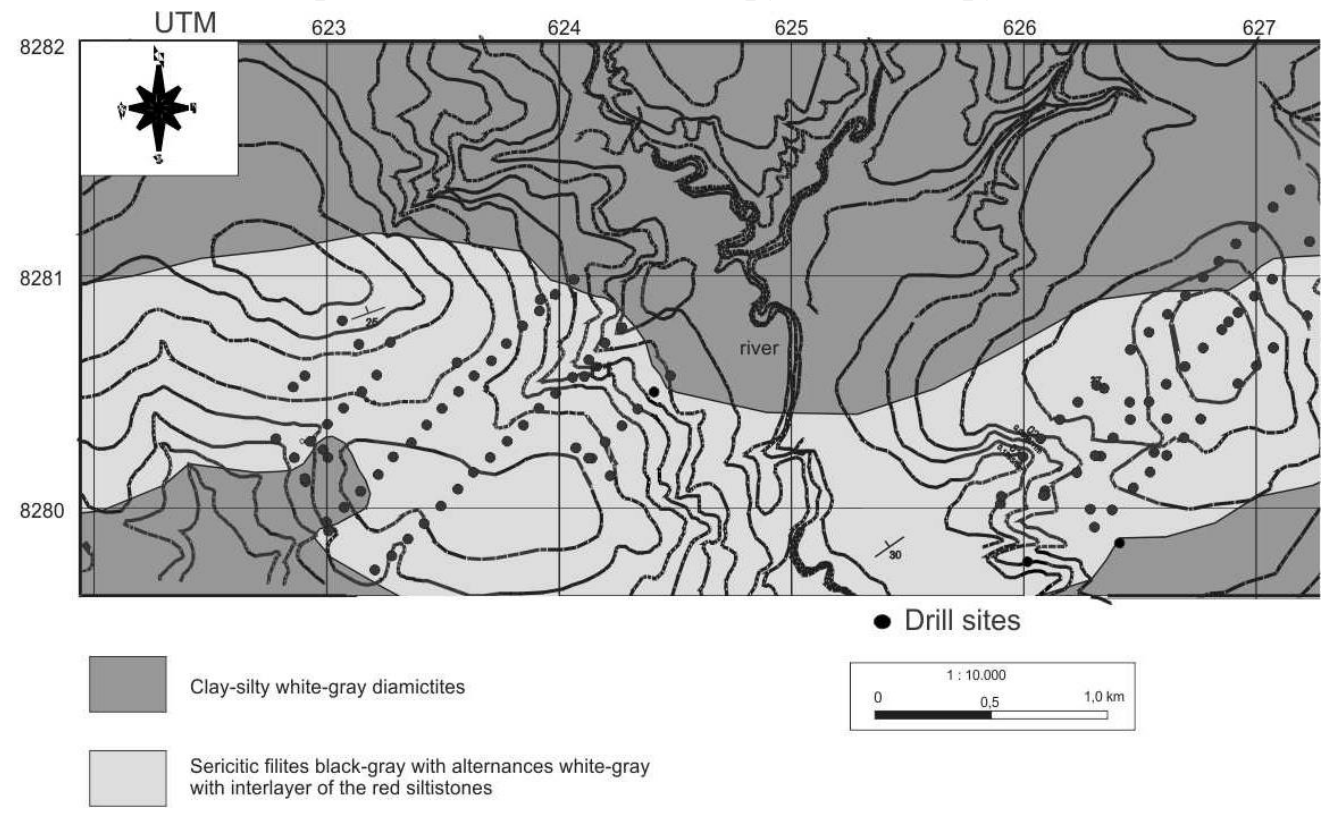

Figure 9 - Geologic map of the Casa de Pedra gold deposit. Bore hole locations are shown.

The bedding is the primary structure observed in this deposit, easily distinguished in the filites by the alteration of white-gray and dark-gray layers, mainly dipping $20-30^{\circ}$ to the northwest (Figure 10A). The first deformation phase and the respective $\mathrm{Sn}$ surface are observed in all rocks in the axial plane of the asymmetrical and inverse folds. In the phyllite, the presence of a well-marked ardosian cleavage is observed. The axial plane of these folds has an average direction of $\mathrm{N} 65^{\circ} \mathrm{E}$ dipping $24^{\circ}$ to the northwest (Figure 10B). The dipping values 
increase in the north portion of the area defining a large fold formed during $D n+1$. The second phase foliation $\left(\mathrm{S}_{\mathrm{n}+1}\right)$ appears as spaced cleavage in all rocks, which defines the axial plane in the $\mathrm{N} 40^{\circ} \mathrm{E}$ direction and dip approximately $70^{\circ}$ to the southeast (Figure 10C). This structure had been eventually
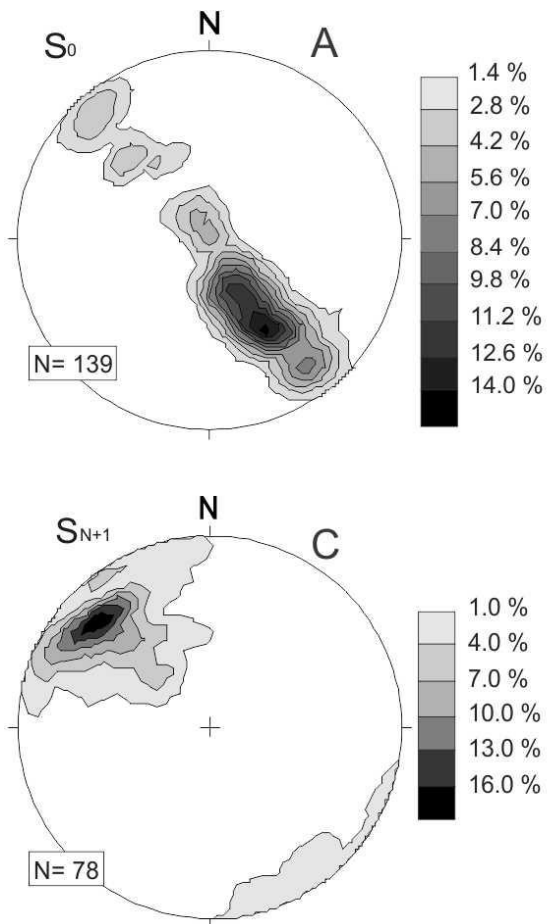

observed as crenulations in the metasiltistones. The third phase is discrete in this deposit, mainly occurring in the phyllite and siltistones as crenulations or as kink bands and soft undulations (open folds) in the diamictites. The fourth phase is orthogonal and is defined by an intense NW subvertical cleavage (Figure 10D).
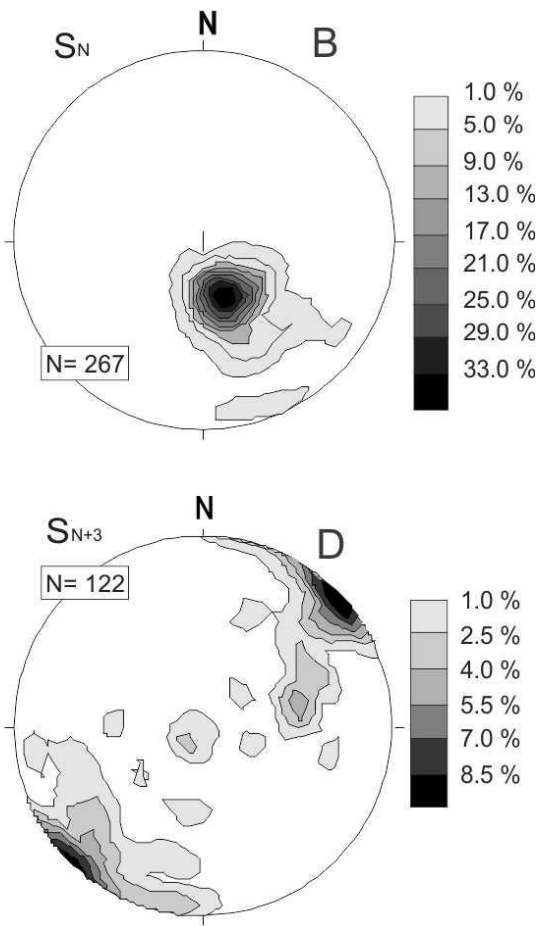

Figure 10 - Structural diagrams of the Casa de Pedra gold deposit.

The quartz veins, observed in the Casa de Pedra gold deposit, might be correlated to the Type 2 (sub-parallel to $\mathrm{Sn}$ ) and Type 3 veins of the NW direction according to Alvarenga (1990) and Silva et al. (2002) (see Figure 11), as described above. Type 2 veins occur parallel to Sn foliation; however, they cut this structure locally with low angles.

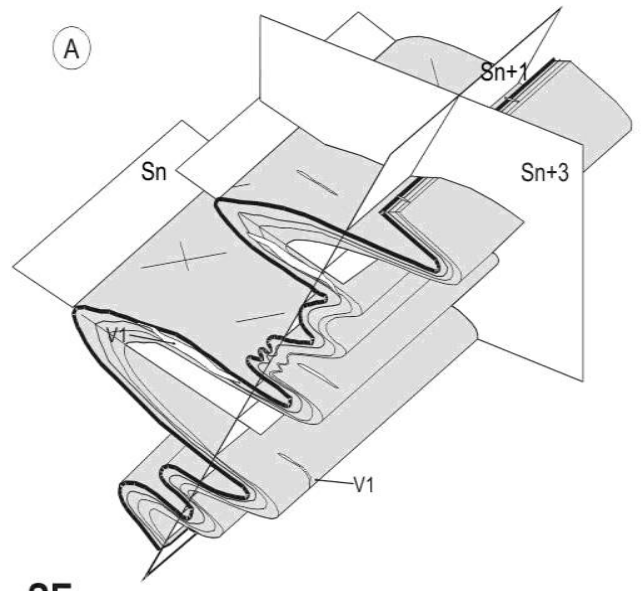

SE

Figure 11. Schematic patterns of folds in the Casa de Pedra gold deposit. A - Foliation planes in relation to the folds. B - Schematic cross open pit wall.

The veins also show boudinage (or pinch and swell), varying from $1 \mathrm{~cm}$ to $70 \mathrm{~cm}$ in thickness and tens of meters in extension. The most common vein of quartz textures are massive and druse; nevertheless, some grained portions are frequent.
The quartz veins with a discontinuous pattern represent Type 3 of approximately $10 \mathrm{~cm}$ thickness. Eventually, they occur in centimetric parallel groups. These veins can be white or orange colored, massive and fibrous, and are used as prospective guider due to their high gold 
concentration. In the hydrothermal halo around the vein, intense cloritization and sulphidization are noticed.

Cangas gold deposits are located approximately $80 \mathrm{~km}$ to the southwest of Cuiabá, next to Poconé city (Figure 2). As in the Casa de Pedra deposit, the gold in Cangas is associated with quartz lodes and disseminated in the host rocks.
The host rocks are comprised of graphitous phyllite, phyllite, meta-pelites, diamictites, ritmites and subordinated sand-stones (Figure 12). The ore minerals are also similar, except for the presence of tourmaline. In Cangas, the first deformational Dn phase developed foliations (Figure 13) in the axial plain of isoclinal and recumbent folds of hundreds of meters of amplitude.

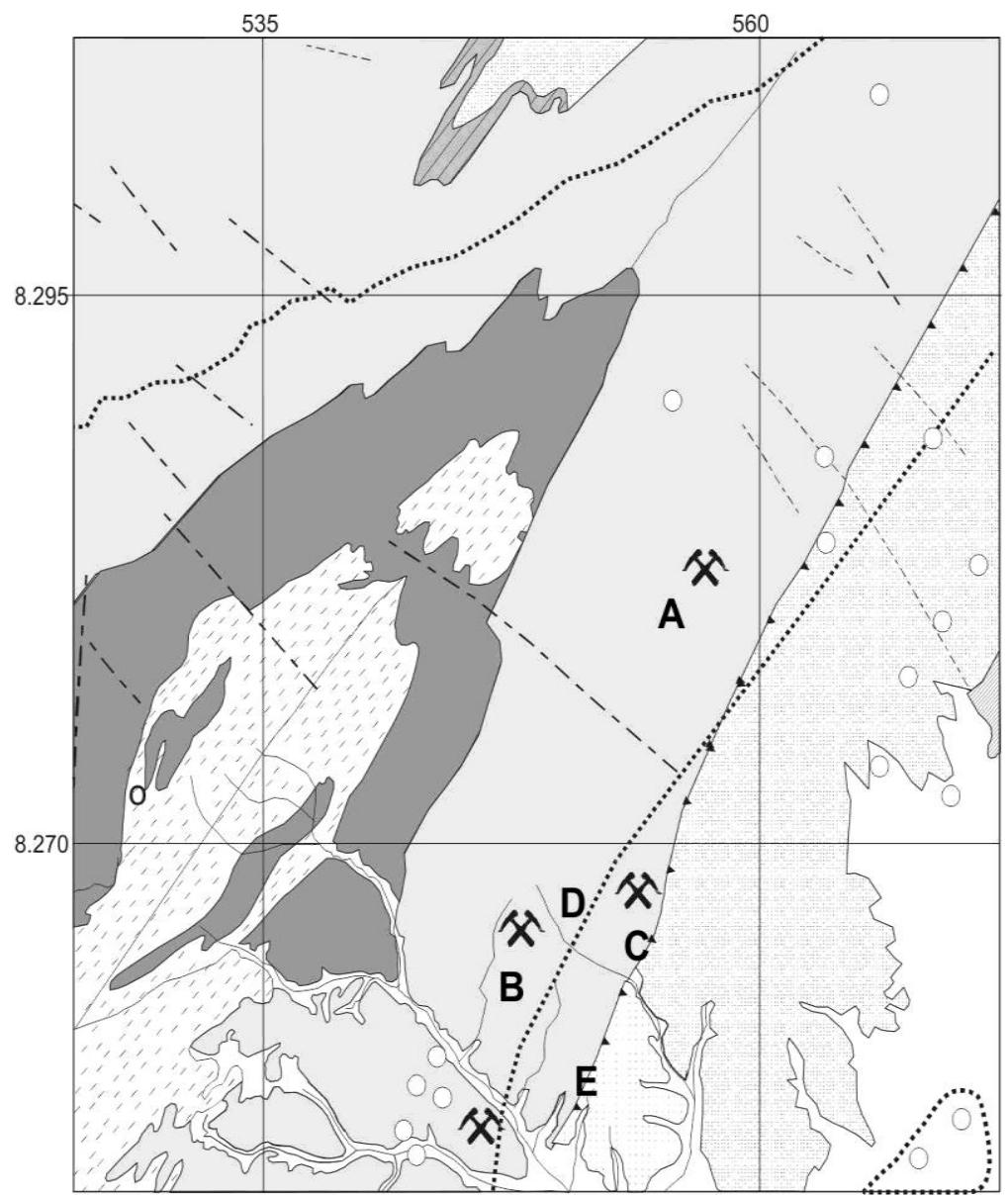

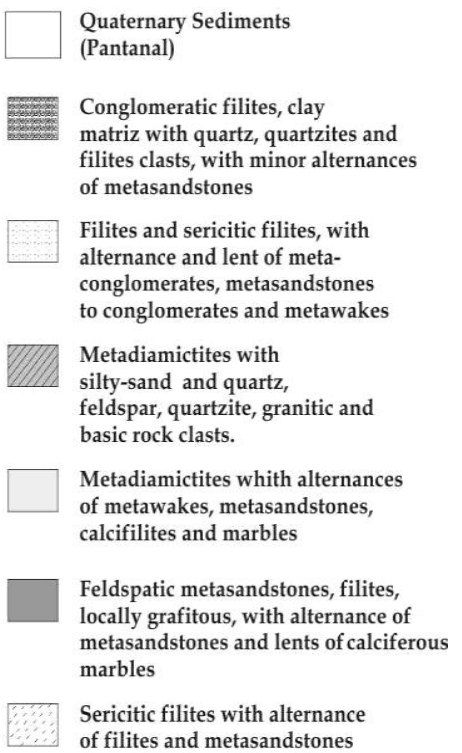

\section{Gold deposits}

\author{
A $=$ Cotia Mining \\ $\mathrm{B}=$ Pingo de Ouro Mining \\ $\mathrm{C}$ and $\mathrm{D}=$ Adão Mining \\ $\mathrm{E}=$ São Rafael Mining
}

Other minor deposits

Figure 12 - Geologic map of the Cangas gold deposits (Modified from Luz et., 1980).

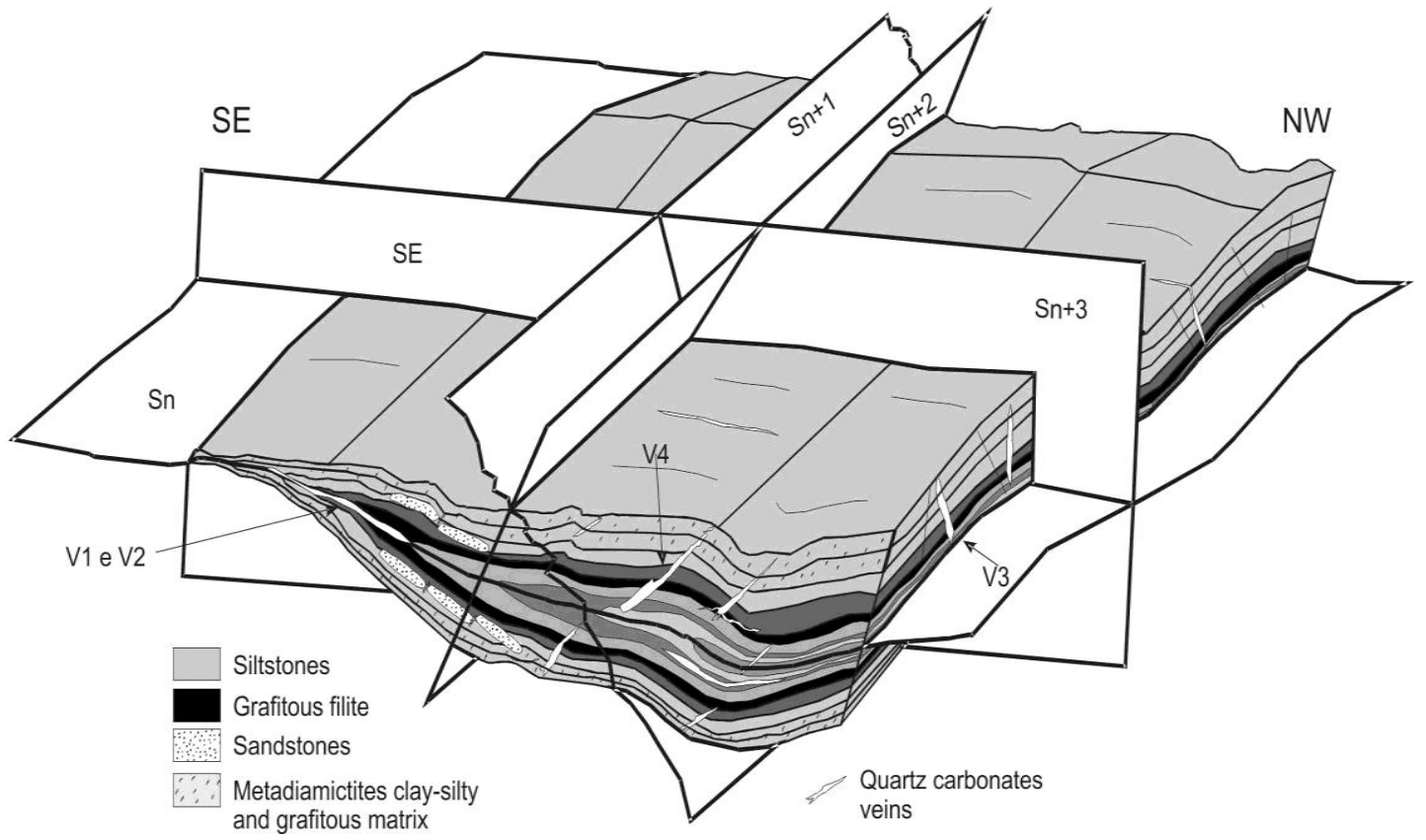

Figure 13 - Schematic deformational planes related to folds in the Cangas gold deposits. 
The foliation $(\mathrm{Sn})$ is marked by the planar orientation of the micaceous minerals. It shows an average attitude of $\mathrm{N} 50^{\circ} \mathrm{E}$ dipping $18^{\circ} \mathrm{NW}$ (Figure $14 \mathrm{~A}$ ), and it is deformed in open folds, the axes of which plunge softly to the NE and $\mathrm{SW}$. The stretching lineations plunge to NE $\left(\mathrm{N} 10^{\circ} \mathrm{E}\right.$, subhorizontal). The $\mathrm{D}_{\mathrm{n}+1}$ phase (Figure $14 \mathrm{~B})$ generated a foliation in the axial plain of opened folds with an amplitude of a few meters.

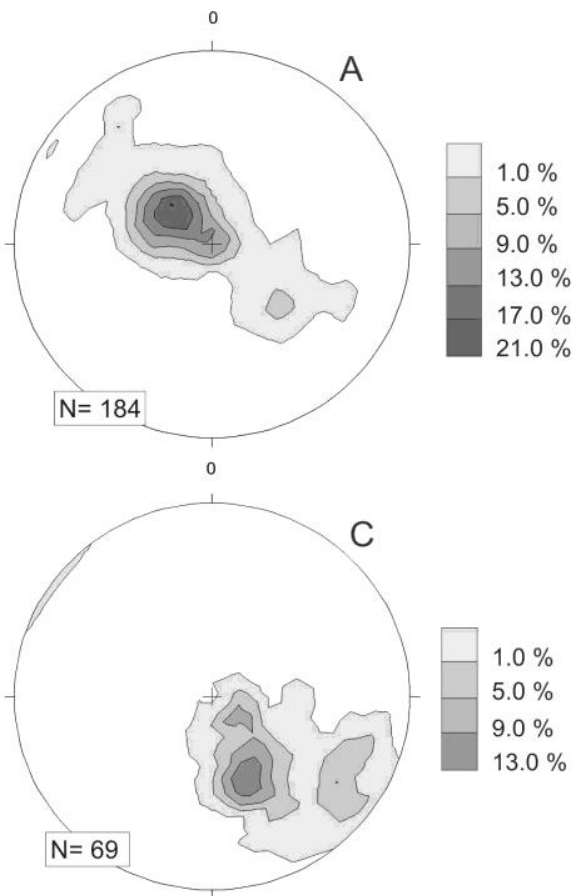

This foliation has an orientation of approximately $\mathrm{N} 70^{\circ} \mathrm{E}$ dipping $36^{\circ}$ to $\mathrm{NW}$. The third, Dn+2 phase (Figure $14 \mathrm{C}$ ) is recorded as a foliation of axial plan of asymmetrical folds, observed in outcrop scale. The axial plan of these folds has a strike of $\mathrm{N} 35^{\circ} \mathrm{E}$ dipping $66^{\circ}$ to SE. The fourth phase (Figure $14 \mathrm{D}$ ) is marked by a cleavage, with an orientation of approximately $\mathrm{N} 10^{\circ} \mathrm{W}$ with high angle (ca. $\left.90^{\circ}\right)$ dipping to SW

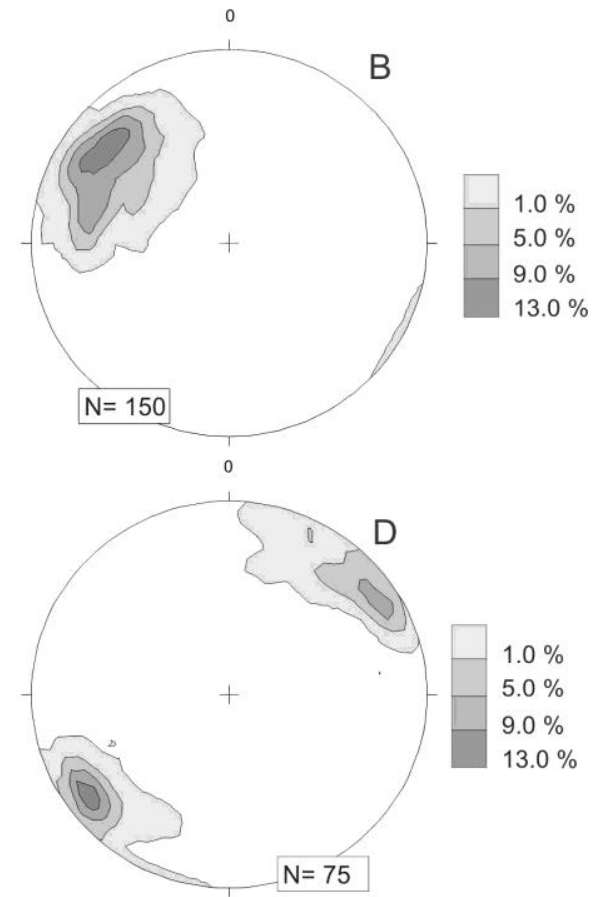

Figure 14 - Structural diagrams of planar structures of the Cangas gold deposits. (A) Sn average is N50 ${ }^{\circ} \mathrm{E}$ dipping $18^{\circ}$ $\mathrm{NW}$; (B) $\mathrm{Sn}+1$ average is $\mathrm{N} 70^{\circ} \mathrm{E}$ dipping $36^{\circ}$ to $\mathrm{NW}$; $\mathrm{Sn}+2$ average is $\mathrm{N} 35^{\circ} \mathrm{E}$ dipping $66^{\circ}$ to $\mathrm{SE}$.

Dn folds have large amplitudes, and this fact makes the differentiation between $S_{0}$ parallel (Type 1) and the Type 2 veins difficult. The latter are parallel to Sn, except in the hinge of the Dn folds, where it is possible to notice Type 1 veins cutting S0 (see Figure 12). There are subvertical veins in the NW direction (Type 3), as in the Casa de Pedra deposit; however, two varieties were observed. The first is 2 or $3 \mathrm{~cm}$ wide and is discontinuous, and the second is up to $15 \mathrm{~cm}$ thick. In addition, there are quartz veins (Type 4), which are parallel to $\mathrm{Sn}+2$. Characteristics of the quartz veins of the Cangas gold deposits are classified in detail as follows.

Type 1: They are boudined according to the main foliation $(\mathrm{Sn})$ plane. The length of these structures reaches hundreds of meters. Their thickness varies from $30 \mathrm{~cm}$ to $1-2 \mathrm{~cm}$. In some portions within the quartz vein, massive texture is observed; however, in other portions, feldspatic and carbonate minerals are common. The presence of quartz, feldspar and carbonate minerals might suggest diverse periods of fluid percolation due cutting features. In the interior of the vein, fragments of host-rocks and carbonate minerals occur. Moreover, sulfides (probably pyrite), clorite, white mica and hematite are also seen in the adjacent hydrothermal halo; Type 2 veins (parallel to $\mathrm{Dn}+1$ ), as described in the Casa de Pedra gold deposit, are geometrically similar to Type 1 veins.

Type 3: These quartz veins only occur in Cangas gold deposits. They occur parallel to $\mathrm{Sn}+2$ and probably are sin-to-late $\mathrm{Dn}+2$; therefore, they cut the limbs of the Dn folds. The length of these veins can reach tens of meters, and the maximum observed thickness was $2 \mathrm{~m}$, composed of quartz with massive and druse textures. In this vein, there are fragments of the host-rock, pyrite (grains up to $2 \mathrm{~cm}$ ) and black weathered carbonate preserving the rhombohedric pattern.

Type 4: These veins are filling NW fractures and present the highest gold contents. This 
family of veins presents two distinct varieties: the first one has lengths of $5 \mathrm{~m}$ and thicknesses of approximately $10-20 \mathrm{~cm}$. They are tabular and show massive texture; the second variety is less thick (up to $5 \mathrm{~cm}$ ), discontinuous and generally red colored due to oxide alteration.

The São Vicente Granite is a large batholite $(30 \times 40 \mathrm{~km})$ located $70 \mathrm{~km}$ to the southeast of Cuiabá (Figure 2). This intrusive body is hosted by diamictites and filites of an undivided subunit of the Grupo Cuiabá (Luz et al., 1980). The contact with host-rocks is marked by an aureole of metamorphism characterized by the presence of the pyroxen-hornfels facies (Almeida, 1964), which had between 400 to $2000 \mathrm{~m}$ of distance from the granite. The main lithotypes are biotitegranites and muscovite-biotite-granites with wide textural patterns; however, the compo- sitions are restricted from monzo to sienogranite (Leite et al., 2001). The granites present subalcaline and peraluminous characters, Si-rich (73 to $80 \%$ ) with S-type characteristics. The granitic bodies were probably formed by biotite, plagioclase and apatite fractionation, as evidenced by REE studies (Leite et al., 2002).

In the São Vicente Granite quarries, four fractured domains and one subhorizontal brittle shear zone can be distinguished (Figure $15 \mathrm{~A}$ ). This shear zone has its main plane marked by a planar anisotropy, characterized by a cataclastic zone of approximately $20 \mathrm{~cm}$ of thickness and a hundred meters of extension. The kinematic analysis of this shear zone suggests top transport to the northwest, conforming to the observed sliken lines present in the lateral limits of this shear zone (Figure $15 \mathrm{~B}$ ).
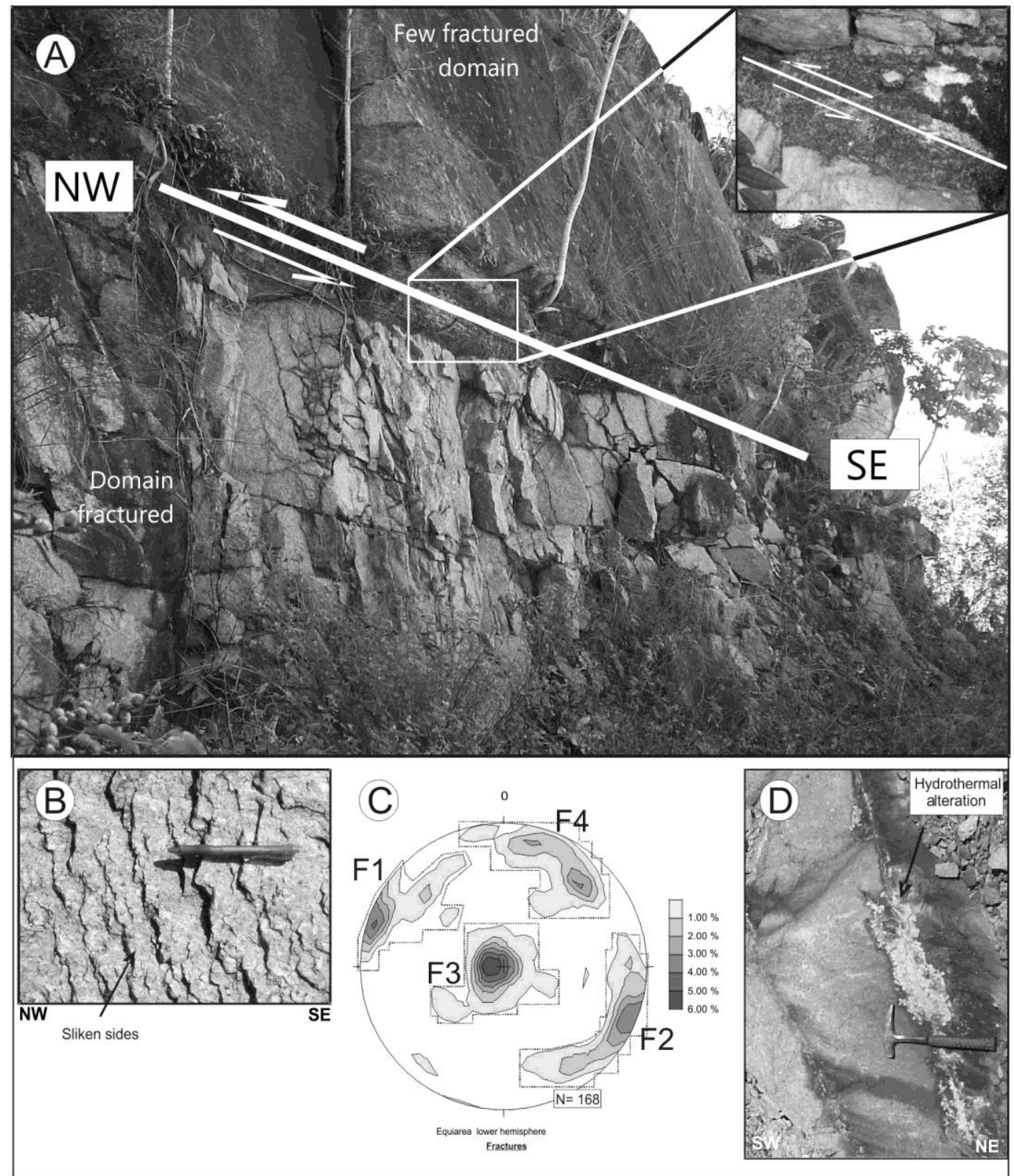

Figure 15 - São Vicente Granite. A - Brittle low angle shear zone with fractured domain (below) and few-fractured domain (above). B - Slink sides in the granite. C - Diagram of fractures. D - NW fracture filled with hydrothermal alteration. 
The fracturing system defines four groups, named F1, F2, F3 and F4 (Figure 15 C). The first and the second group are conjugated fractures with NE-SW trends and high dip angles (dipping to NW and SE). The third group has a NNW-SSE trend and lower dip (about $15^{\circ}$ ) to EES-WWN. The forth group of the fractures (F4) has a N40$60 \mathrm{~W}$ trend and dip between $50-70^{\circ}$ to the southwest.

Another interesting aspect of the fractures is the presence of hydrothermal alteration filling, mainly composed of pyrite and arsepyrite (Figure $15 \mathrm{D})$. This hydrothermal alteration appears to be restricted to $\mathrm{F} 4$, which is parallel to the cleavage filled with Au-rich in the auriferous deposits described above, suggesting cogenetic formation. The host-rocks of São Vicente Granite show an expressive vergence to the southeast, different than the observed vergence in the granite shear zone, suggesting that the granite planar structure is probably related to the second deformation phase $\left(\mathrm{D}_{\mathrm{N}+1}\right)$ of the Paraguay Belt.

\section{CONCLUSIONS}

The stratigraphic interpretations of the Paraguay Belt has undergone many changes in the last decades. The most accepted proposals have interpreted that the rocks of the Internal, External and Platformal Domains take part of the same basin, deposited in glaciomarine environment in the proximal sites of the Cratonic area, toward deeper marine with influence of the turbidite flows in distal areas (Alvarenga, 1990). Cap carbonates of the Araras Group overlay these diamictites (related to Marinoan glaciation). On the top, diamictites and siltstones of the Serra Azul Formation are observed, related to Gaskiers Glaciation (Figueiredo et al., 2004; Alvarenga, 2006) and terrigenous sediments of Alto Paraguay Group, represented by sandstones of Raizama and claystones of Diamantino formations.

The structural and geological studies conducted in the Paraguay Belt suggest that four deformation phases are registered in the Paraguay Belt rocks, so does Alvarenga \& Trompette (1993). These four phases were formed during progressive and continuous deformation. The first phase is more intense and generated foliation and regional asymmetrical inverse folds. It has a fan geometry, showing vergence to the Cratonic area next to the Nobres region (northern sector), a vertical pattern in the central portion and vergence to the southeast in the Cuiabá and Poconé regions. The second and third deformation phases appear as axial plan of the metric folds, cleavage or crenulations. The late deformation phase is orthogonal and presents open kilometric folds at the regional scale.

The Nobres region is located next to the tectonic contact between the External and Internal Domains of the Paraguay Belt, which is marked by inverse faults, laterally limited by transference faults. The vergence of the structures, generated during the Neoproterozoic deformation in the Paraguay Belt indicates mass transport towards to Amazonian Craton.

In the auriferous deposits of the Internal Domain of the Paraguay Belt, four types of quartz veins were observed: Type 1 parallel to bedding $\mathrm{S}_{0}$, Type 2 parallel to $\mathrm{Sn}$ foliation, Type 3 parallel to $S_{n+1}$, and Type 4 perpendicular to $S n$. The Au-rich veins are mainly of Type 4 that probably had an origin related to extension fractures during orogeny collapse (Alvarenga, 1990). In the Casa de Pedra gold deposits, only Type 2 and Type 3 quartz veins occur; in Cangas gold deposits, Type 3 quartz veins that cut the hinge of folds $\mathrm{D}_{\mathrm{n}+2}$ parallel to $\mathrm{Sn}$ and $\mathrm{Sn+1}$ (Type 1 and 2) and Type 4 quartz veins, which are perpendicular to $\mathrm{Sn}$ and $\mathrm{Sn}+1$, occur. The metallogenetic components of these deposits is quartz, clorite, biotite, albite, carbonates, epidot, rutile, pyrite, chalcopyrite and hematite.

The evolution of the Paraguay belt was recently explained by the existence of the Paranapanema Block, as defined by Mantovani et al. (2003), also denominated by Soares (1988) as the Parana Block, which is corroborated by the gravimetric studies reported by Mantovani et al. (2003). This block was first referred to by Cordani et al. (1985), comprising the embasement of the Parana Basin. These authors suggested that this block is constituted of a pre-Cambrian cratonic nucleus of igneous and metamorphic rocks surrounded by Brazilian mobile belts. Later work by Zalán (1990) and Quintas (1995) corroborate the proposal of Cordani et al. (1985), including small changes regarding the geometry of the Paranapanema block. In contrast, did not propose just one nucleus but three. Mantovani et al. (2003) distinguished the northern limit of the Paranapanema Block with the Goias Magmatic Arc, Brasilia Belt and the southern border with Rio de La Plata Block. 


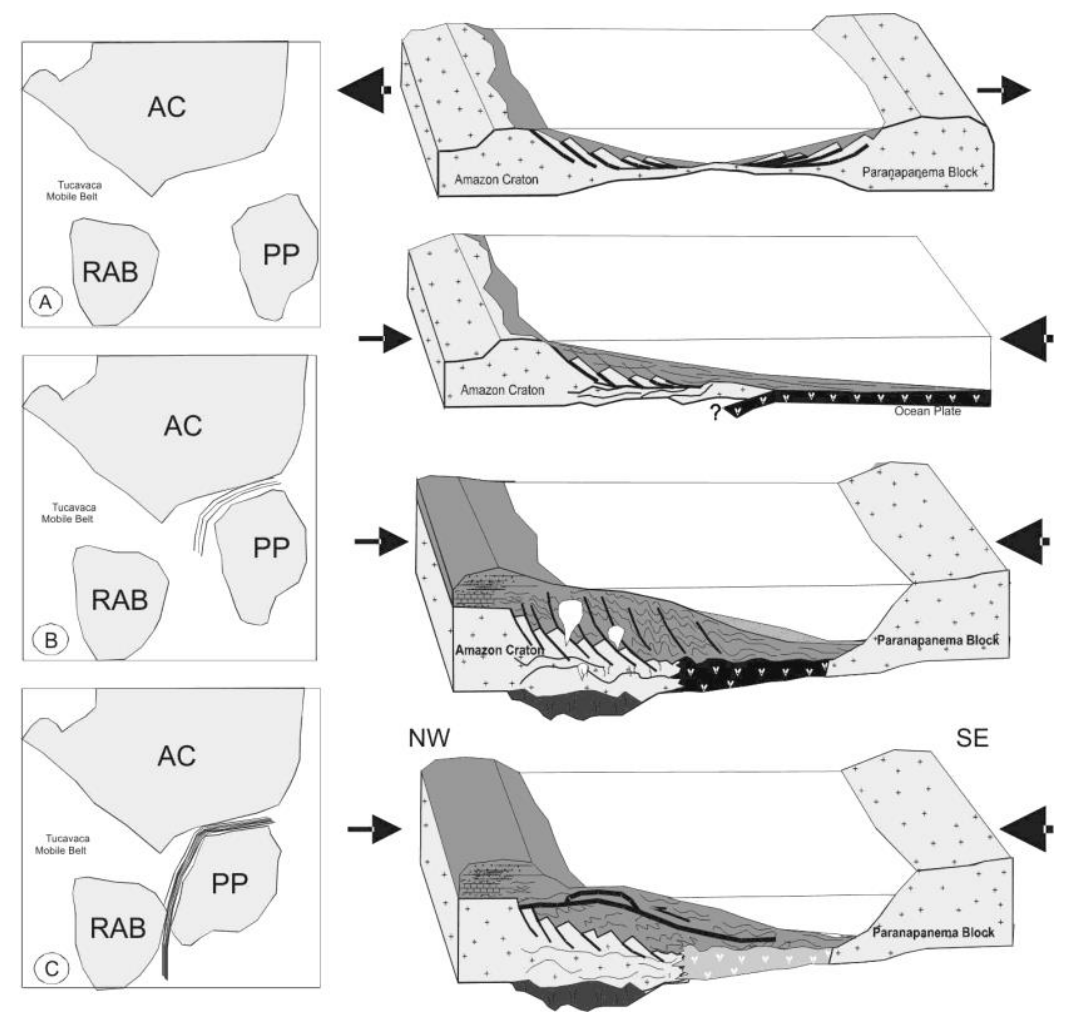

Figure 16 - Geologic evolution model for the Paraguay Belt. See text for discussion.

Map captions: $\mathrm{AC}=$ Amazonian Craton; $\mathrm{PP}=\mathrm{Paranapamenema} \mathrm{Block} ; \mathrm{RAB}=\mathrm{Rio}$ de La Plata Block.

The fact that the Paranapanema Block was overlapped by the Paraná Basin makes it difficult to include this block in the reconstruction models of Gondwana (Brito Neves, 2003), but the evidence of the existence of this tectonic unit, as well as the necessity of studies that aim to delimitate their marginal limits, appears to be consented to all of the authors above cited.

The analysis of the Paraguay Belt tectonic features defines a more penetrative foliation dipping to NNW in the Nova Xavantina region (Pinho, 1990; Gheler, 1997). Near Cuiabá city, the foliation presents a NW dip, and, in Mato Grosso do Sul, the foliation dips to the E. Another important structural aspect of the outcrops of the rocks in Nova Xavantina region, cited by Martinelli (1999), is the marked slideslip dextral shear (E-W). These observations, associated with age intervals of the metamorphism cooling ages (541-531 Ma) in the Nova Xavantina region (Geraldes et al., 2003) and the age of the Granito São Vicente (504 \pm 12 Ma) near Cuiabá city, suggest that the close of the ocean started in the eastern part of the Paraguay Belt (Figure 16A), taking into account the collision of the Paranapanema Block with the Amazonian Craton. The collision probably developed towards the Cuiabá region (Figure 16B), finally closing the ocean in the southern portion of the Paraguay Belt with the collision of the Paranapanema and Rio Apa block (Figure 16C).

\section{ACKNOWLEDGMENTS}

The authors acknowledge the contribution of several colleagues from Federal University of Mato Grosso. MCG thanks CNPq for research fellowship (process 301470/2016-2).

\section{REFERENCES}

ALMEIDA, F.F.M. Geologia do Centro-Oeste Mato Grossense. Rio de Janeiro, DNPM/DGM, Bol. 214. 137 p., 1964.

ALMEIDA F.F.M. Província Tocantins-setor sudoeste. In: ALMEIDA \& HASUI (eds.). O Pré-Cambriano do Brasil. São Paulo, Ed. Bluncher. p. 265-281. Rio de Janeiro, MME. p. 25-160. (Levantamento de recursos Naturais 27), 1984.

ALMEIDA, F.F.M. \& MANTOVANI, M.S.M. Geologia e Geocronologia do Granito São Vicente, Mato Grosso. Anais da Academia Brasileira de Geociências, Rio de Janeiro, v. 47, p. 451-458, 1975.
ALVARENGA, C.J.S. Dobramentos da Faixa Paraguai na Borda Sudeste do Craton Amazônico. In: CONGRESSO BRASILEIRO DE GEOLOGIA, 35, 1984, Belém. Anais... Belém: Sociedade Brasileira de Geologia, 1984, p. 3258-3271. ALVARENGA, C.J.S. Phénomènes Sèdimentaires, Structuraux et Circulation de Fluides Dèveloppes à la Transition Chaîne - Craton Exemple de la Chaîne Paraguai d'âge Proterozoique Supérieur, Mato Grosso, Brésil. Marseille. 177 p. (Thèse Doct. Sci. Univ. Aix. Marseille III), 1990.

ALVARENGA C.J.S. \& SAES, G. Estratigrafia e Sedimentologia do Proterozóico Médio e Superior da região 
sudeste do Cráton Amazônico. Revista Brasileira de Geociências, v. 22, n. 4, p. 493-499, 1992.

ALVARENGA C.J.S. \& TROMPETTI, R. Evolução Tectônica Brasiliana da Faixa Paraguai: A Estruturação da Região de Cuiabá Revista Brasileira de Geociências, v. 18, p. 323-327, 1993.

ALVARENGA, C.J.S.; SANTOS, R.V.; DANTAS, E.L. C-O-Sr isotopic stratigraphy of cap carbonates overlying Marinoan-age glacial diamictites in the Paraguay Belt, Brazil. Precambrian Research, v. 131, p. 1-21, 2004.

ALVARENGA, C.J.S.; FIGUEIREDO, M.F.; BABINSKI, M. ; PINHO, F.E.C. Glacial diamictites of Serra Azul Formation (Ediacaran, Paraguay Belt): evidence of the Gaskiers glacial event in Brazil. CONGRESSO BRASILEIRO DE GEOLOGIA, 33, 2006, Rio de Janeiro. Anais...Rio de Janeiro: Sociedade Brasileira de Geologia, 2006, CD ROM.

BARBOZA, E.S., GERALDES, M.C. 2004. Mapeamento Litoestrutural da Sinclinal da Guia, Grupo Cuiabá - Faixa Paraguai-MT (dados preliminares). In: XLII Congresso Brasileiro de Geologia, Araxá-MG, Anais em CD-ROM multimídia.

BARBOZA, E.S. \& SANTOS JR., W.A. Mapeamento litoestrutural e geoquímico da Sinclinal da Guia, Município de Cuiabá - MT. In: Simpósio de Geologia do Centro-Oeste, VIII, 2003, Cuiabá-MT, Boletim de Resumos... Cuiabá: Sociedade Brasileira de Geologia, 2003, p. 136-138.

BARBOZA, E.S., GERALDES, M.C., PINHO, F.E.C., 2005. The vergence of the Paraguay Belt in the Context of the collage of the West Gondwana. In: 1st Symposium on NeoproterozoicEarly Paleozoic Events in SW-Gondwana, IGCP Project 478 , IGUSP, p. 3-5.

BARBOZA, E.S., GERALDES, M.C., PINHO, F.E.C., FERNANDES, C.J, SILVA, C.H., 2006. Stratigraphic and structural aspects of the Paraguay Fold and Thrust Belt: implications for mineral deposits and collage of the Gondwana. In: Anais do XLIII Congresso Brasileiro de Geologia, Aracajú, p. 30.

BARBOZA, E.S.; PULZ, G.M.; RONCHI, L.H.; PINHO, F.E. Inclusões fluidas nos veios de quartzo do depósito Pau-a-Pique, sudoeste do Cráton Amazônico. In: Caracterização e modelamento de depósitos minerais. RONCHI \& ALTHOFF, Editora Unisinos, p. 293-311, 2003.

BARBOZA, E.S., SANTOS, A.C., PINHO, F.E.C., FERNANDES, C.J., GERALDES, M.C., 2018. Paraguay Belt lithostratigraphic and tectonic characterization: implications in the evolution of the orogen (Mato Grosso-Brazil). Journal of Sedimentary Environments 3 (2), 54-73

BARROS, A.M.; SILVA, R.M.; CARDOSO, O.R.F.A.; FREIRE, F.A.; SOUZA, J.J.JR.; RIVETTI, M.; LUZ, D.S.; PALMEIRA, R.C.B.; TASSINARI, C.C.G., Geologia, In: Radambrasil, Folha SD-21 Cuiabá. Rio de Janeiro, MME - SG, (Levantamento de Recursos Naturais), 26, p. 25 - 192, 1982.

BOGGIANI, P.C.; FAIRCHILD, T.R.; COIMBRA, A.M. O Grupo Corumbá (Neoproterozóico-Cambriano) na região central da Serra da Bodoquena (Faixa Paraguai), Mato Grosso do Sul. Revista Brasileira de Geociências, v. 23, n. 3, p. 301 305, 1993.

BRITO NEVES, B.B A Saga dos Descendentes de Rodínia na construção do Gondwana. Revista Brasileira de Geociências, v. 33, n. 1, p. 77-88, 2003.

BRITO NEVES, B.B.; CAMPOS NETO, M.C.; FUCK, R. From Rodinia to Western Gondwana: An Approach to the BrasilianoPan-African Cycle and Orogenic Collage. Episodes, v. 22, p. 155-166, 1999.

BROGGI JR., J.; LOTUFO, L.S.; GONÇALVES, L.S. Contribuição ao conhecimento geológico da área urbana de Poconé. Cuiabá, 1994. 94 p. Trabalho (Conclusão de curso de Geologia) - UFMT.

CAMPANHA, G.A.C.; BOGGIANI, P. C.; SALLUN FILHO, W.; SÁ, F.R.; ZUQUIM, M.P.S.; PIACENTINI, T. A faixa de dobramento Paraguai na Serra da Bodoquena e depressão do Rio Miranda, Mato Grosso do Sul. Geologia USP. Série
Científica, v. 11, p. 79-96, 2011.

CAMPOS, E.G.; XAVIER, R.P.; OLIVEIRA, S.M.B. Caracterização dos fluidos mineralizantes relacionados aos veios de quartzo auríferos do Grupo Cuiabá. In: Congresso Brasileiro de Geoquímica, 1, Porto Alegre, 1987. Anais...Porto Alegre: Sociedade Brasileira de Geologia, v. 1, 1987, p. 417-435.

CORDANI, U.G.; BRITO NEVES, B.B.; FUCK, R.A.; PORTO, R.; THOMAS FILHO, A.; CUNHA, F.M.B. Estudo preliminar de integração do Pré-Cambriano com os eventos tectônicos das bacias sedimentares Brasileiras. Revista Ciência Técnica Petróleo, n. 15. Petrobrás, CENPES, CINTEP. 70 p., 1985.

COSTA, J.L.G.; RUIZ, A.S.; WEBER, F.; BARROS, A.J.P. Controle estrutural do depósito aurífero da Fazenda Salinas, Poconé - MT. In: CONGRESSO BRASILEIRO DE GEOLOGIA, 40, 1998, Belo Horizonte. Anais...Belo Horizonte: Sociedade Brasileira de Geologia, 1998.

DEL'ARCO, J.O.; SILVA, R.H.; TARAPANOFF, I; FREIRE, F.A.; PEREIRA, L.G.M.; SOUZA, S.L.; LUZ, L.G.; PALMEIRA, R.C.B.; TASSINARI, C.C.G. Geologia do PréCambriano na Folha SE.21. Corumbá. In: SIMPÓSIO DE GEOLOGIA DO CENTRO-OESTE, 1, 1981, Goiânia. Anais...Goiânia: Sociedade Brasileira de Geologia, p. 154176,1981

DOWLING, K. \& MORRINSON, G. Application of quartz textures to the classification of gold deposits using North Queensland examples. Economic Geology; Monograph, v. 6, p. $342-355,1989$.

FIGUEIREDO, M.F. Quimioestratigrafia das rochas Ediacarianas do extremo norte da Faixa Paraguai, Mato Grosso. São Paulo, 105 p. 2006. Dissertação (Mestrado) Universidade do Estado de São Paulo.

FIGUEIREDO, M.F.; BABINSKI, M.; ALVARENGA, C.J.S.; PINHO, F.E.C. Diamictites overlying Marinoan-age carbonates of Araras Formation, Paraguay Belt, Brazil: evidence of a new glaciation? Symposium on Neoproterozoic-Early Paleozoic Events in SW-Gondwana, In: IGCP Project 478, Second Meeting, Brazil, p. 18-19, 2004

GAUCHER, C.; BOGGIANI, P.C.; SPRECHMANN, P., SIAL, A.N.; FAIRCHILD, T. Integrated correlation of the Vendian to Cambrian Arroyo del Soldado and Corumbá Groups (Uruguay and Brazil): palaeogeographic, palaeoclimatic and palaeobiologic implications. Precambrian Research, v. 120, Issues 3-4, 10, p. 241-278, 2003.

GERALDES, M. C.; TASSINARI, C.C.G.; BABINSKI, M.; MARTINELLI, C. D.; IYER, S. S.; BARBOZA, E.S., PINHO, F.E.C.; ONOE, A.T.. 2003 . Isotopic evidence for the Late Brasiliano (500-550 Ma) ore-forming mineralization of the Araés gold deposit, Brazil.. International Geology Review, v.49, p. $177-190$.

GERALDES, M.C.; TASSINARI, C.C.G.; PAULO, V.G.; PALERMO, N.; VASCONCELOS, P. ${ }^{40} \mathrm{Ar} /{ }^{39} \mathrm{Ar}$ (541-531 Ma) Cooling ages of the Paraguay Belt in the Nova Xavantina (MT) region: Tectonic Implications to Western Gondwana Collage Anuário do Instituto de Geociências, v. 41, n. 3, p. 351-362, 2018.

GHELER, W.L. Contribuição à geologia do Grupo Cuiabá, na região do Rio Jatobá - Campinápolis/MT. Cuiabá, 1997. 62 p. Trabalho (Conclusão do curso de Geologia) - UFMT

HENNIES, W.T. Geologia do Centro-Norte Mato-Grossense. São Paulo, 65 p. 1966. Tese (Doutorado) - Escola Politécnica, Universidade de São Paulo.

HORTENSI, R.A.A. O Contexto Litoestrutural das Mineralizações Auríferas na Região de Poconé - MT. Campinas, 75 p., 1999. Dissertação (Mestrado) - Universidade de Campinas.

LEITE, J.A.D.; QUADROS, A.P.; FIGUEIREDO, M.F. Petrologia e Faciologia do Granito São Vicente. In: ENCONTRO DE INICIAÇÃO CIENTÍFICA, IX Cuiabá, 2001. Anais...Cuiabá: PIBIC-CNPQ/UFMT, 2001.

LEITE, J.A.D.; QUADROS, A.P.; FIGUEIREDO, M.F. Geoquímica e ambiência Tectônica do Granito São Vicente da 
Faixa de Dobramentos Paraguai/ MT. In: ENCONTRO DE INICIAÇÃO CIENTÍFICA, IX Cuiabá, 2002. Anais...Cuiabá: PIBIC-CNPQ/UFMT, 2002.

LUZ, J.S.; OLIVEIRA, A.M.; SOUZA, J.O.; MOTTA, J.F.M.; TANNO, L.C.; CARMO, L.S.; SOUZA, N.B. Projeto Coxipó, Goiânia, DNPM/CPRM, Rel. 36 p., 1980.

MANTOVANI, M.S.M.; BRITO NEVES, B.B.; QUINTAS, M.C.L.; SHUKOWSKY, W. Geophysical definition of Paranapanema Proterozoic Block and its importance for the Rodinia to Gondwana evolutionary theories. Geophysical Research Abstracts, European Geophysical Society, v. 5, 2003.

MARTINELLI, C.D. Petrografia, estrutural e fluidos da mineralização aurífera dos Araés - Nova Xavantina - MT Rio Claro, 183 p. 1999. Tese (Doutorado), Pós-Graduação em Geociências - Universidade Estadual Paulista.

MIGLIORINI, R.B. Hidrogeologia em Meio Urbano. Região de Cuiabá e Várzea Grande - MT. São Paulo, 146 p. 1999. Tese (Doutorado) - Instituto de Geociências, Universidade de São Paulo.

NOGUEIRA, A.C.R., A plataforma carbonática Araras no sudoeste do Cráton Amazônico, Mato Grosso: Estratigrafia, contexto paleoambiental e correlação com os eventos glaciais do Neoproterozóico. São Paulo, 2003. 173 p. Tese (Doutorado), Instituto de Geociências da Universidade de São Paulo.

NOGUEIRA, A.C.R.; RICCOMINI, C.; SIAL, A.N.; MOURA, C.A.V.; TRINDADE, R.I.F.; FAIRCHILD, T.R. Carbon and strontium isotope flutuations and paleoceanographic changes in the late Neoproterozoic Araras carbonate platform, southern Amazon craton, Brazil. Chemical Geology, v. 237, p. 168-190, 2007.

PIACENTI, T.; BOGGIANI, P.; YAMAMOTO, J.K.; FREITAS, B.T.; CAMPANHA, G.A.C. Formação ferrífera associada à sedimentação glaciogênica da Formação Puga (Marinoano) na Serra da Bodoquena, MS. Revista Brasileira de Geociências, v. 37, p. 530-541, 2007.

PINHO, F.E.C. Estudo das rochas encaixantes dos veios mineralizados a ouro do Grupo Cuiabá na região denominada "Garimpo do Araés", Nova Xavantina Estado de Mato Grosso. Porto Alegre, 1990. 114 p. Dissertação (Mestrado) - Instituto de Geociências, Universidade Federal do Rio grande do Sul.

PINHO, F.E.C.; SIAL, A.N.; FIGUEIREDO, M.F., Contribution to the Neoproterozoic $\mathrm{C}$-and $\mathrm{O}$-isotopic record: carbonate rocks from the Paraguay Belt, Mato Grosso, Brazil. In: South American Symposium on Isotope Geology, IV, 2003, Salvador, Brazil. Short Papers...Salvador, v. 1, p. 390-393.

PIRES, F.R.M.; GONÇALVEZ F.T.T.; SIQUEIRA A.J.B. Controle da Mineralizações Auriferas do Grupo Cuiabá, Mato Grosso. In: CONGRESSO BRASILEIRO DE GEOLOGIA, 34 , 1986, Goiânia. Anais...Goiânia: Sociedade Brasileira de Geologia, 1986, v. 5, p. $2383-2396$.
QUINTAS, M.C.L. O embasamento da Bacia do Paraná: reconstrução geofísica de seu arcabouço. São Paulo, 213p. 1995. Tese (Doutorado) - Instituto Astronômico e Geofísico, Universidade de São Paulo.

RUIZ, A.S.; SILVA, C.H.; SIMÕES, L.S.A. O caráter coaxial da deformação principal nas rochas do Grupo Cuiabá, Faixa Paraguai, Centro-oeste do Brasil. In: SIMPÓSIO DE GEOLOGIA DO CENTRO OESTE, VII, Brasília. Anais...Brasília: Sociedade Brasileira de Geologia, 1999, CDROM.

SILVA, C.H. Caracterização Estrutural de Mineralizações Auriferas do Grupo Cuiabá, Baixada Cuiabana (MT). Rio Claro, 1999. 134 p. Dissertação (Mestrado) - Instituto de Geociências de Ciências Exatas, Universidade Estadual Paulista.

SILVA, C.H.; SIMÕES, L.S.A.; RUIZ, A.S. Caracterização estrutural dos veios de quartzo auríferos da região de Cuiabá (MT). Revista Brasileira de Geociências, v. 32, n. 4, p. 407418, 2002.

SILVA, L.J.H.D. Ouro no Grupo Cuiabá, Mato Grosso: controles estruturais e implicações tectônicas. In: CONGRESSO BRASILEIRO DE GEOLOGIA, XXXVI, Natal, 1990. Anais.... Natal: Sociedade Brasileira de Geologia, 1990, v. 6, p. 2520-2534.

SOARES, P.C. Tectônica colisional em torno do Bloco Paraná, Brasil. In: CONGRESSO LATINO AMERICANO DE GEOLOGIA, Belém, 1988. Anais...Belém: Sociedade Brasileira de Geologia, 1988, p. 63-79.

SOUZA, M.Z.A. Petrologia e geoquímica do complexo alcalino Ponta do Morro - MT. São Paulo, 1997. 168 p. Tese (Doutorado) - Instituto de Geociências, Universidade de São Paulo.

TRINDADE, R.I.F. Low-latitude and multiple geomagnetic reversals in the Neoproterozoic Puga cap carbonate, Amazon craton. Terra Nova, v. 15, n. 6, p. 441-446, 2003.

TROMPETTE, R. Geology of Gondwana (2000-500 Ma). PanAfrican-Brasiliano aggregation of South America and Africa, 350 p., 1994.

ZALÁN, P.V.; WOLFF, S.; ASTOLFI, M.A.M.; VIEIRA, I.S.; CONCEIÇÃO, J.C.; APPI, V.T.; NETO, E.V.S.; CERQUEIRA, J.R., MARQUES, A. The Paraná Basin, Brazil. In: Interior Cratonic basins. Bulletin of the American Association of Petroleum Geologists, memoir 51, p. 681 707, 1990 